



\section{Exploring the impacts of two Brexit scenarios on Dutch agricultural trade flows}

S. van Berkum, R.A. Jongeneel, M.G.A. van Leeuwen and I.J. Terluin

This study was carried out by Wageningen Economic Research and was commissioned and financed by the Dutch Ministry of Agriculture, Nature and Food Quality within the context of the 'Theme name' research theme of the Policy Support/Knowledge Base/Statutory Research Tasks (project number BO-20-019-074 KD-2017-062)

Wageningen Economic Research

Wageningen, February 2018

REPORT

2018-026

ISBN 978-94-6343-261-0 
Van Berkum, S., R.A. Jongeneel, M.G.A. van Leeuwen and I.J. Terluin, 2018. Exploring the impacts of two Brexit scenarios on Dutch agricultural trade flows. Wageningen, Wageningen Economic Research, Report 2018-026. 40 pp.; 11 fig.; 13 tab.; 22 ref.

This report provides a quantification of the effects of two possible post-Brexit trade scenarios on Dutch agricultural trade. Dutch exports to the UK and the rest of the world will be affected only marginally under a Free Trade Agreement between the EU and the UK. A WTO scenario will have more yet still relatively modest impacts on Dutch exports. With total agricultural exports slightly declining, Dutch exports of pig meat and tomatoes to the UK even increase as a result of Dutch price competitiveness at the UK market and greater price responsiveness of production (and exports) in other EU MS countries. The agricultural production value in the Netherlands will decline by around $2 \%$, mainly because of declining prices that are the result of price pressure at the EU market as a consequence of Brexit-related trade distortions.

In dit rapport wordt een schatting gemaakt van de effecten van twee mogelijke handelsscenario's die de toekomstige handelsrelatie van de EU met het VK simuleren voor de agrarische handel van Nederland. De Nederlandse export naar het VK en de rest van de wereld zal maar weinig merken van een Vrijhandelsakkoord tussen de EU en het VK. Een WTO-scenario heeft wel meer maar toch ook beperkte effecten voor de Nederlandse export. Terwijl de totale agrarische export in dat scenario enigszins afneemt, neemt de Nederlandse export van varkensvlees en tomaten naar het VK juist toe vanwege het prijsconcurrerend vermogen van het Nederlandse aanbod op de Britse markt en de sterkere prijsreacties van productie (en export) in andere EU-lidstaten. De agrarische productiewaarde in Nederland neemt met grofweg $2 \%$ af, vooral vanwege lagere prijzen die het gevolg zijn van prijsdruk op de Europese markt als ten gevolge van Brexit de handel met het VK wordt verstoord.

Key words: Brexit, UK, Dutch agricultural exports, scenarios

This report can be downloaded for free at https://doi.org/10.18174/441200 or at www. wur.eu/economic-research (under Wageningen Economic Research publications).

(C) 2018 Wageningen Economic Research

P.O. Box 29703, 2502 LS The Hague, The Netherlands, T +31 (0)7033583 30,

E communications.ssg@wur.nl, http://www.wur.eu/economic-research. Wageningen Economic Research is part of Wageningen University \& Research.

\section{(cc) BY-NC}

For its reports, Wageningen Economic Research utilises a Creative Commons Attributions 3.0 Netherlands license.

(C) Wageningen Economic Research, part of Stichting Wageningen Research, 2018

The user may reproduce, distribute and share this work and make derivative works from it. Material by third parties which is used in the work and which are subject to intellectual property rights may not be used without prior permission from the relevant third party. The user must attribute the work by stating the name indicated by the author or licensor but may not do this in such a way as to create the impression that the author/licensor endorses the use of the work or the work of the user. The user may not use the work for commercial purposes.

Wageningen Economic Research accepts no liability for any damage resulting from the use of the results of this study or the application of the advice contained in it.

Wageningen Economic Research is ISO 9001:2008 certified.

Wageningen Economic Research Report 2018-026 | Project code 2282500224

Cover photo: Luca De Gregorio/Shutterstock.com 


\section{Contents}

$\begin{array}{ll}\text { Summary } & 5\end{array}$

1

$\begin{array}{ll}\text { Introduction } & 6\end{array}$

2

$\begin{array}{ll}\text { Current trade flows } & 8\end{array}$

2.1 Introduction $\quad 8$

2.2 Agricultural exports and imports $\quad 8$

$3 \quad$ Scenarios definitions and model simulation results $\quad 14$

3.1 Two Brexit scenarios and a baseline $\quad 14$

$\begin{array}{lll}3.2 & \text { Issues with respect to tariff rate quota } & 15\end{array}$

$\begin{array}{lll}3.3 & \text { Static comparative price analysis under the WTO scenario } & 17\end{array}$

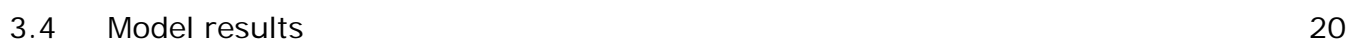

3.4.1 Effects of Brexit scenarios on the UK side $\quad 20$

3.4.2 Effects on Dutch exports and production value 21

3.4.3 Summarised outcomes and qualifications of model simulation results 24

$\begin{array}{ll}\text { References and websites } & 27\end{array}$

Appendix 1 AGMEMOD: description of the model 29

Appendix 2 Interviews with the industry highlighting non-tariff issues in trade $\quad 32$

Appendix 3 Dutch trade data for selected sector ( related to Appendix 2) 34

$\begin{array}{lll}\text { Appendix } 4 & \text { Trade elasticities explained } & 36\end{array}$ 



\section{Summary}

For the Netherlands, the UK is an important trade partner in agricultural products: $10 \%$ of all Dutch agricultural exports finds its way to the UK and 3\% of all Dutch imports has its origin in the UK. Dutch products account for $13 \%$ of all UK agricultural imports, indicating the relatively strong position of the Netherlands in UK's agricultural import market. The main Dutch agricultural export products to the UK are meat (especially poultry meat), ornamental plants, fresh vegetables (especially tomatoes and peppers), followed by fruits and prepared vegetables and fruits. Dutch imports from the UK are largely beverages (whiskeys), beef and cheese.

Focusing on meat, dairy and tomato as Dutch key traded products, model projections of a Free Trade Agreement (FTA) show minor effects on bilateral trade flows between the Netherlands and the UK. A WTO scenario, on the other hand, implies additional trade costs and import tariffs, of which the latter are relatively high for beef, butter and cheese. This leads in the first place to less import needs of the UK, which affects Dutch exports to the UK negatively for beef, poultry and cheese in particular, whereas exports of pig meat and tomato increase somewhat. In absolute terms, impacts on Dutch exports are modest. Overall, the effects on production values foregone by Brexit are 3.3\% for poultry, $2.3 \%$ for cheese, close to $2 \%$ for pig meat and beef and $1 \%$ for tomato. These effects are dominated by the price depressing effect on Dutch and other EU countries' domestic markets that follows a Brexit. Effects of possibly divergence of non-tariff measures that may add to trade costs are not included in the model simulations, yet discussed qualitatively, mainly based on interviews and literature. 


\section{Introduction}

The Brexit vote implies negotiations to establish new trade relationships between the EU27 and the UK. Compared with the single market conditions of free trade of goods, capital and persons, new trade relations will most likely be accompanied by trade costs due to the introduction of tariffs and other than tariff policy regulations that affect trade, the so-called non-tariff measures (NTMs). Since the then prime minister David Cameron decided in 2013 to hold a referendum on EU-membership, a range of studies has been conducted to simulate the impact of future trade relationships on trade flows between the EU27 and the UK. Often, these studies use an 'optimistic' scenario, in which a Free Trade Agreement (FTA) between the EU27 and the UK is assumed next to a 'pessimistic' scenario in which trade between the EU27 and the UK is subject to World Trade Organisation (WTO) Most Favoured Nation (MFN) terms. Six of those studies summarised in Emerson et al. (2017) produce a relative consistent result which is that both parties will face economic losses, but disproportionally between them in money amounts in ratio of around 1 to 2 or 1 to 3 for the UK and EU27 respectively. In terms of percentages of GDP, the accumulated losses up to 2030 for the UK average between $1.3 \%$ and $4.2 \%$ for the optimistic and pessimistic scenario, respectively; those for the EU27 average $0.1 \%$ and $0.5 \%$ respectively. These relative differences in GPD losses show the asymmetric nature of the trade policy implications of Brexit: whereas EU27 Member States only face rising trading costs with one country, the UK is confronted by rising trading costs from all 27 EU Member States and rising trade barriers from EU's FTA partner countries.

I mpact Brexit depends on intensity of trade relationship with the UK Some EU Member States have a more intense trade relationship with the UK than others due to historic ties or geographical location. The degree of intensity of the trade connection can be denoted with the indicator of openness, which shows the proportion of the country's imports from and exports to the UK relative to the country's GDP (Rojas-Romagosa, 2016). The openness of trade with the UK of Belgium, Cyprus, Denmark, Ireland, Malta and the Netherlands is well above the EU27 average. As a result, estimates for GDP losses in 2030 in the majority of these countries in both the optimistic and pessimistic Brexit scenarios are slightly above the EU27 average. However, I reland is more severely affected with estimated GDP losses between 3 and $4 \%$.

Decline in agricultural exports to the UK is partially offset by redirection of trade flows Only few studies focus on the impact of Brexit on agricultural trade flows between the UK and individual Member States. Donnellan and Hanrahan (2016) simulate consequences for the I rish agrifood exports, which for over $40 \%$ are accounted by the UK. In an optimistic (hence UK-EU FTA) Brexit scenario, total I rish agri-food exports will decline by about 1.5\%, while exports will decrease by more than $7 \%$ in a pessimistic scenario. The decline in I rish agri-food exports to the UK is larger than these percentages show, because less export to the UK is partially offset by an increase in the exports to other destinations. Other studies also point at these trade redirection effects of Brexit. For instance, Yu et al. (2017) estimate that Danish agricultural exports to the UK decline by about $40 \%$ in an optimistic Brexit scenario and by $80 \%$ in a pessimistic scenario (mainly due to the relatively high estimated non-tariff measures trade costs on pork meat and dairy, which are Danish main export products to the UK), but total Danish agricultural exports will reduce only by $3-4 \%$. Banse and Freund (2017) estimate the impact of Brexit on German's agricultural exports for a pessimistic (hence WTO) scenario only and find less than half of the reduction in agri-food exports to the UK is redirected to other countries, which results in a decline of total German agricultural export by $10 \%$. RojasRomagosa (2016) estimates that total Dutch exports of primary agricultural products will decline by $0.2 \%$ in an optimistic Brexit scenario and by $1 \%$ in a pessimistic scenario; the reduction of total exports of processed foods amounts to over $6 \%$ and nearly $10 \%$ respectively. However, this estimation does not explicitly show the decline in Dutch agri-food exports to the UK, nor does it detail the consequences of the EU leaving the EU per product. 
Objective and approach of this study

This study aims to explore the impacts of two Brexit scenarios on the trade flows of the Dutch agricultural sector. It especially focuses on changes in both total agricultural exports and exports of individual agricultural products between the Netherlands and the UK; the Netherlands and the rest of the EU; and the Netherlands and third countries. By using the partial equilibrium model AGMEMOD the study will quantify the impacts of Brexit scenarios. See Appendix 1 for details of the model and the data used in the model. In addition, several interviews with sector representatives and experts are conducted in which specific market characteristics and market access issues are discussed that are not specified by the AGMEMOD model.

The Brexit scenarios in this study follow the common approach used in many quantitative analyses of the economic impacts of Brexit. As baseline scenario we use a situation in which the UK remains a member of the EU. Our two alternative trade scenarios are:

1. a Free Trade Agreement (FTA) scenario, in which there is free trade between the UK and the EU27 (the 'optimistic' scenario);

2. a WTO scenario, in which the UK and the EU27 trade on Most Favoured Nations (MFN) terms (the 'pessimistic' scenario).

Projections of these scenarios are reported for the year 2025/2026.

In the model simulations we assume that a new UK food framework with arrangements on food trade and food safety standards has been established. Such a food framework requires huge efforts and a reversal of the current policy deficit in this field as the UK has relied on pan-European institutions (Lang et al., 2017). ${ }^{1}$

Due to the model features and scenario assumptions, the model outcomes may not be able to cover all relevant details of market characteristics (e.g. a dominant supplier; product differentiation/nonsubstitutable products), nor will it report on products at a further detailed level than included in the model set-up. Moreover, the modelling work is limited to what can be quantified. For example, it doesn't consider what would be the impact on trade if the UK government would decide to introduce border procedures and/or product standards that divert from what is applied in the EU. For that reason, model outcomes are supplemented by interviews with industry experts that fill some of these gaps to some extent. The interviews are conducted for tomatoes, cheese and propagation materials, with the objective to identify post-Brexit trade issues which are expected to have considerable costincreasing effects and which would be highly relevant to address in new EU-UK trade arrangements. The interviews are supplemented by trade data reviews (see Appendix 2 for key bilateral trade features for these products and Appendix 3 for trade data).

Plan of this study

The plan of this study is as follows. In Chapter 2 we focus on current agricultural trade flows from the Netherlands to the UK, the rest of the EU and third countries. In Chapter 3 the Brexit scenarios are explained and model simulation results are presented, discussed and qualified. Conclusions are drawn in Chapter 4.

\footnotetext{
1 Moreover, the model projections also assume a continuation of direct payment support policies in the UK after Brexit, at similar levels as currently as part of the Common Agricultural Policy (CAP) of the EU, and with similar income and production effects.
} 


\section{Current trade flows}

\subsection{Introduction}

In this chapter trade flows between the Netherlands and the UK are analysed in relation to exports to and imports from other countries in order to assess the relative importance of the UK as agricultural trading partner for the Netherlands. First total agricultural export and import flows are discussed, followed by an elaboration on the decomposition of agricultural trade flows in product groups and processing stage.

\subsection{Agricultural exports and imports}

Dutch agricultural exports to the UK and other countries

Figure 2.1 summarises the trade relationship between the Netherlands and the UK in figures. Total Dutch exports amounted to $€ 490 \mathrm{bn}$ in 2016 , of which $9 \%$ was exported to the UK. The share of the UK in total Dutch agricultural exports is $10 \%$. Dutch imports of agricultural products from the UK are only $3 \%$ of the country's total agricultural imports, compared to $5 \%$ import share in all Dutch imports. Total UK exports amounted to over $€ 350$ bn in 2016 of which $6 \%$ was directed at the Netherlands. A slightly higher percentage (7\%) of UK's exports has the destination of the Netherlands when it comes to agricultural products. Looking at UK's agricultural imports, Dutch products account for $13 \%$ of all UK agricultural imports. The latter indicates the relatively strong position of the Netherlands in UK's agricultural import market.

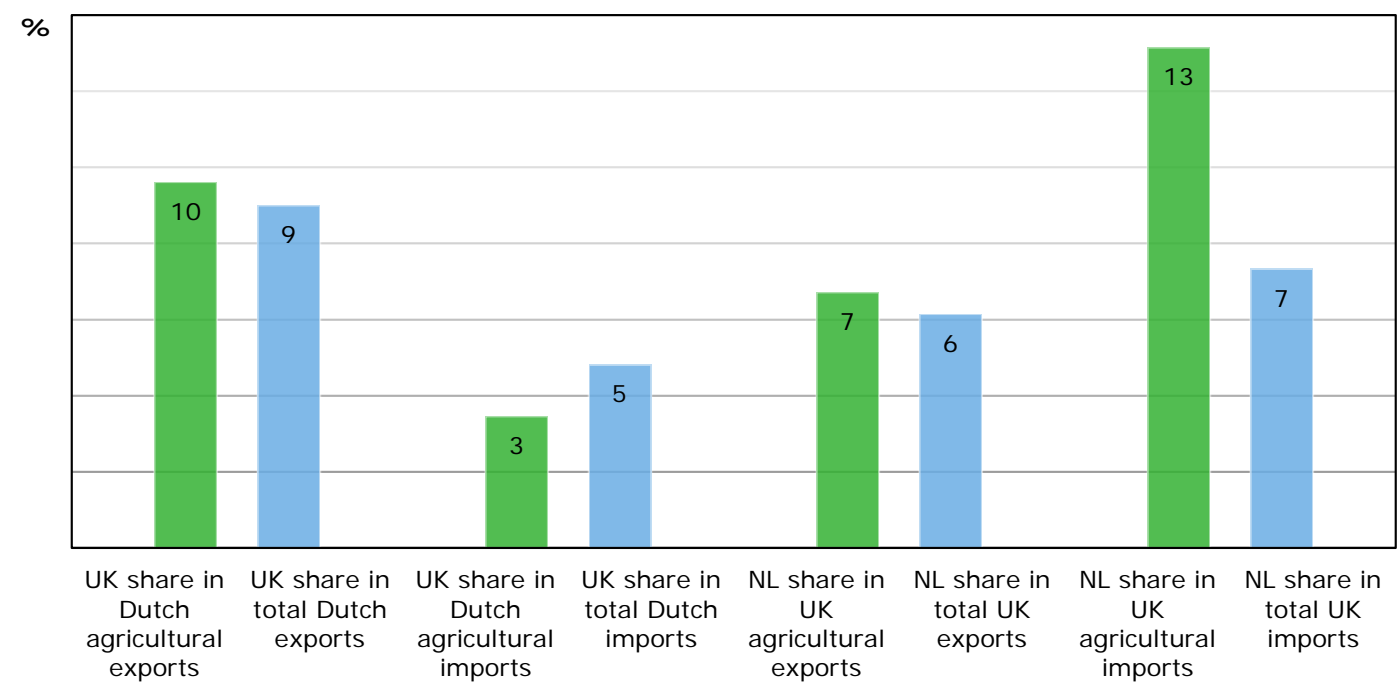

Figure 2.1 The shares of the UK and the Netherlands in each other's exports and imports, 2016 (\% of total) Source: EUROSTAT COMEXT; adaptation Wageningen Economic Research.

As indicated in the previous figure, $10 \%$ of Dutch agricultural exports finds its way to the UK, which means that the UK is the third biggest export market of Dutch agricultural products. Germany is by far the largest agricultural trading partner of the Netherlands by absorbing over one quarter of Dutch agricultural exports, followed by Belgium (Figure 2.2). Other main destinations of Dutch agricultural exports are France, Italy and Spain. 


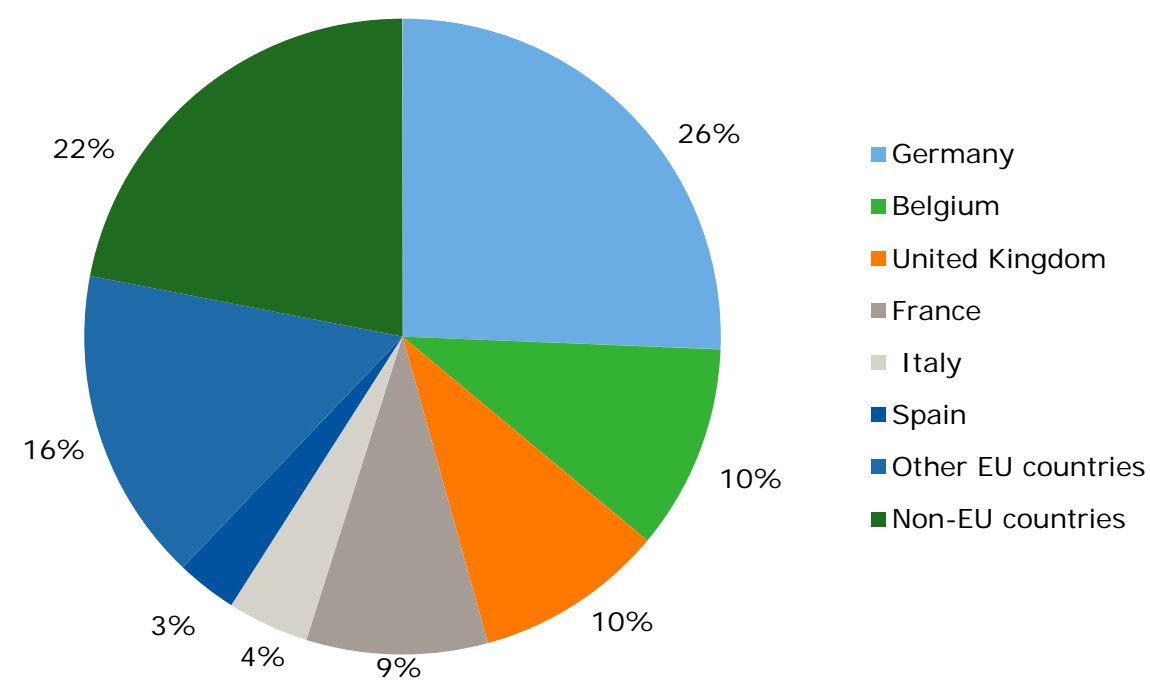

Figure 2.2 Destination of Dutch agricultural exports, 2016 (\% of total) Source: EUROSTAT COMEXT; adaptation Wageningen Economic Research.

In addition to Germany and Belgium, Dutch agricultural imports originate for a considerable part (45\%) from non-EU countries (Figure 2.3 ). Germany and Belgium are by far the EU countries from which the Netherlands imports most. UK's share in Dutch agricultural imports is a moderate $3 \%$.

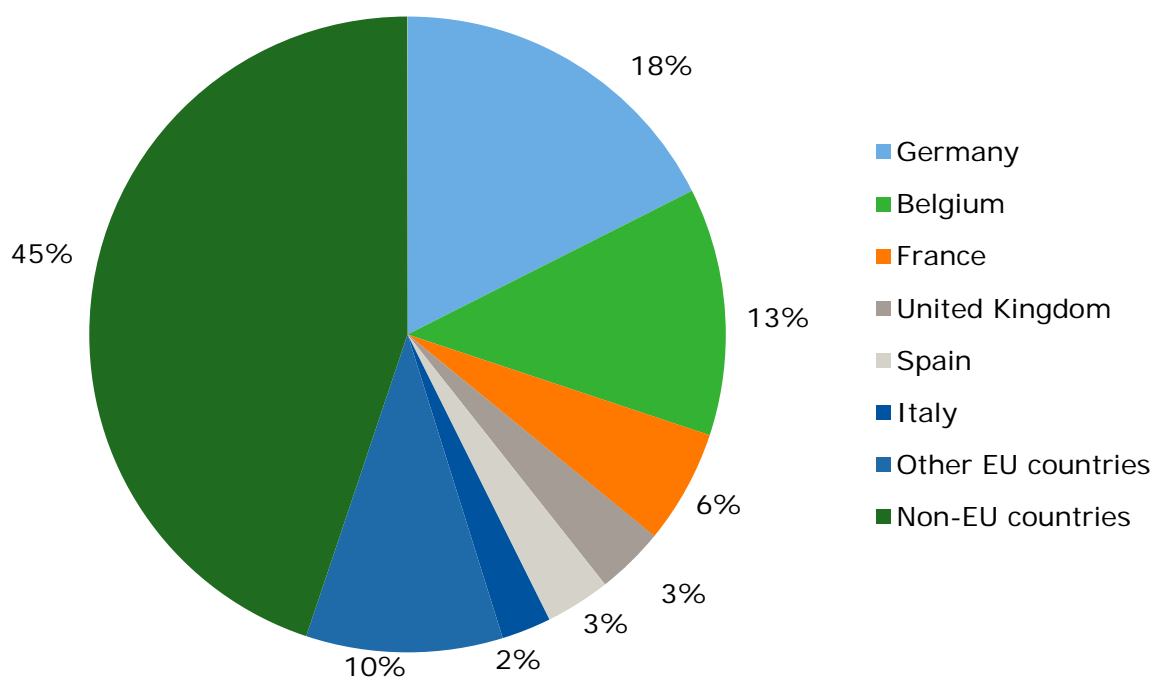

Figure 2.3 Origin of Dutch agricultural imports, 2016 (\% of total) Source: EUROSTAT COMEXT; adaptation Wageningen Economic Research.

Main destinations of UK agricultural exports

About one sixth of UK agricultural exports is traded with I reland (Figure 2.4). The Netherlands has a share of $6 \%$ in total UK agricultural exports and is the third most important export destination of UK's agricultural products in the EU. However, among the EU Member States, the Netherlands is the most important agricultural importer to the UK with a share of $13 \%$ (Figure 2.5), with I reland second, followed by Germany and France. 


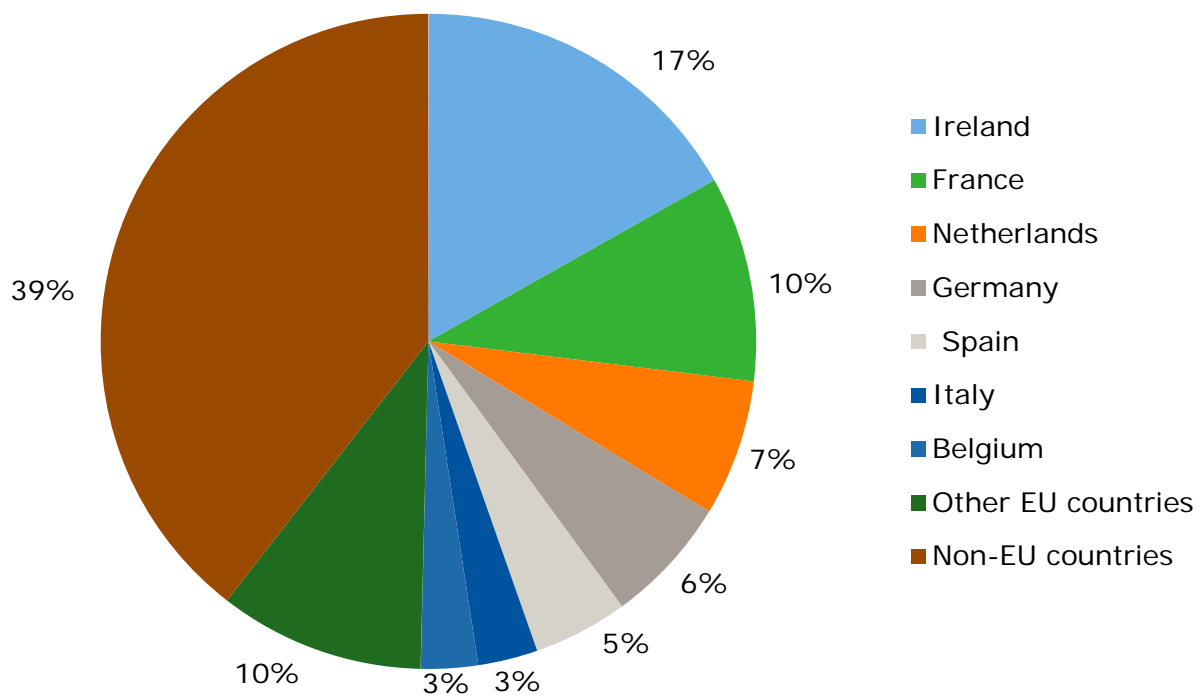

Figure 2.4 Destination of UK agricultural exports, 2016 (\% of total).

Source: EUROSTAT COMEXT; adaptation Wageningen Economic Research.

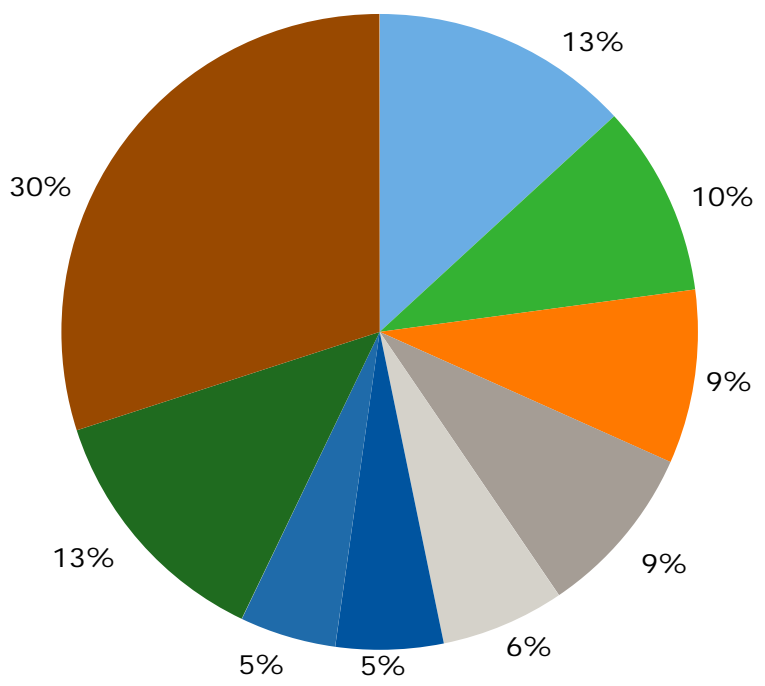

\author{
- Netherlands \\ - Ireland \\ - Germany, Fed. Rep. \\ - France \\ Spain \\ - Italy \\ - Belgium \\ - Other EU countries
}

- Non-EU countries

Figure 2.5 Origin of UK agricultural imports, 2016 (\% of total)

Source: EUROSTAT COMEXT; adaptation Wageningen Economic Research.

The Netherlands exports mainly poultry meat, flowers and vegetables to the UK Main agricultural export products from the Netherlands to the UK are meat (especially poultry meat), ornamental plants and vegetables (especially tomatoes and peppers) (Table 2.1). Other key exported products are fruit, preparations of vegetables and fruits, miscellaneous edible preparations and beverages. Together these seven product groups amount to two thirds of Dutch agricultural exports to the UK (Figure 2.6). The market share of the UK in the total Dutch exports of these seven product groups equals to about $13 \%$. The Netherlands mainly imports beverages (whiskey), miscellaneous edible preparations, meat (beef) and dairy (cheese) from the UK (Figure 2.7). 
Table 2.1 Dutch exports to and imports from the UK specified by products, 2016

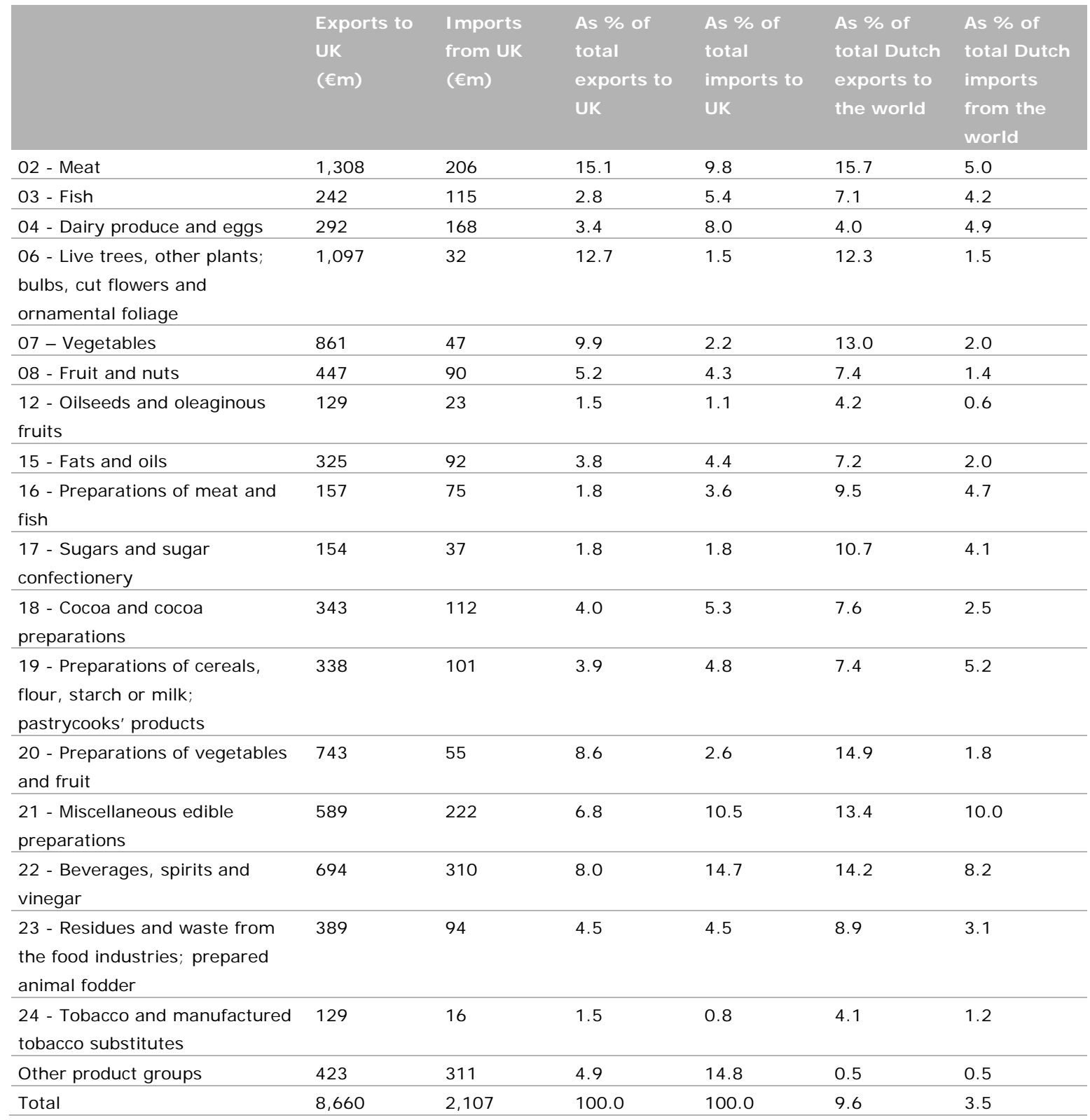

Source: EUROSTAT COMEXT; adaptation Wageningen Economic Research.

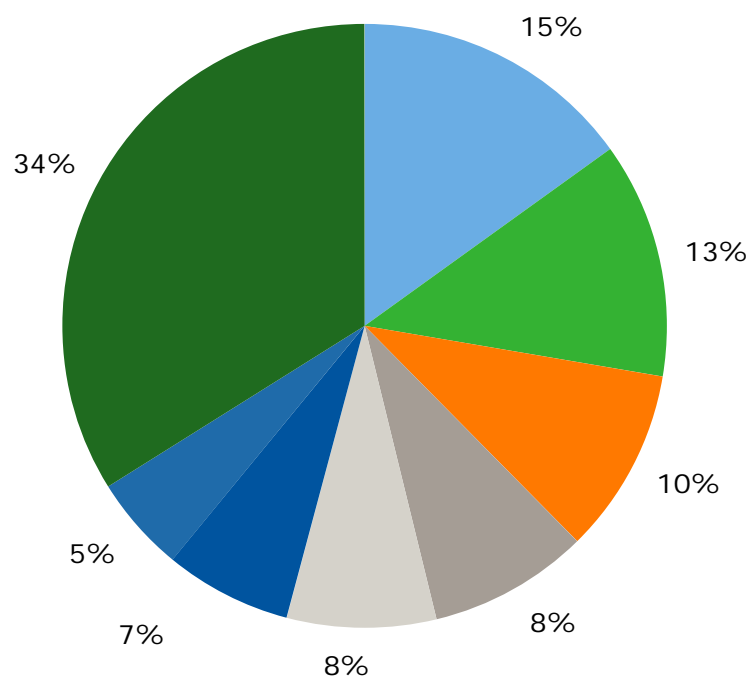

Meat

- Ornamental plants

- Vegetables

Processed vegetable and

fruit

Beverages

- Miscellaneous edible

preparations

- Fruit

- Other products

Figure 2.6 Dutch agricultural exports to the UK per product group, 2016 (\% of total) Source: EUROSTAT COMEXT; adaptation Wageningen Economic Research. 


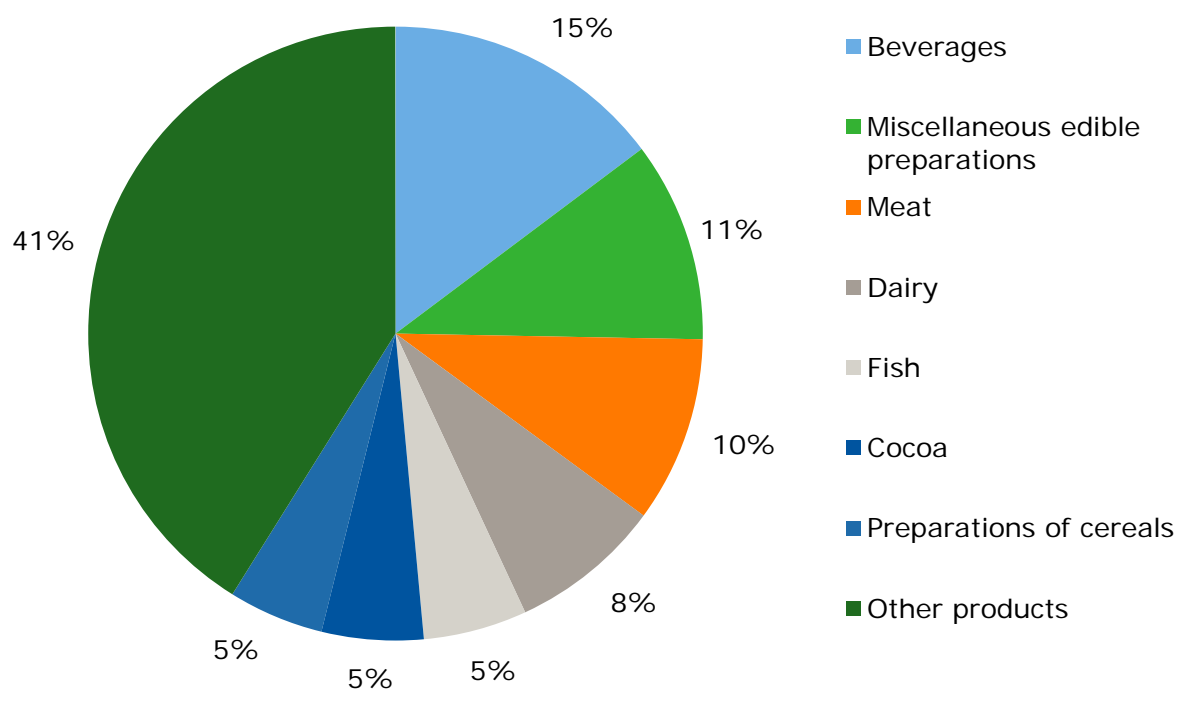

Figure 2.7 Dutch agricultural imports from the UK per product group, 2016 (\% of total) Source: EUROSTAT COMEXT; adaptation Wageningen Economic Research.

Almost $60 \%$ of the Dutch agricultural exports to the UK consists of final products Agricultural exports and imports can be decomposed in product groups or categories reflecting products' processing stage and through this, trade in value added. In Tables 2.2-2.3 agricultural trade flows are split into propagation materials, unprocessed products, semi-processed products, non-fresh final products and fresh final products (for classification of products, see Van Berkum, 2012).

Table 2.2 shows that $50 \%$ of Dutch total agricultural exports (to World) consists of final products (fresh/not fresh; $35 \%$ and $15 \%$ respectively). ${ }^{2}$ Compared to this share in its total exports, these product categories are more important in the Dutch agricultural exports to the UK (namely, 38\% and $18 \%$, respectively). Exports of propagation material are equally important in the Dutch exports to the UK compared to Dutch total trade of products in this category ( $8 \%$ versus $9 \%$ respectively). Un- and semi-processed products are the major categories in Dutch agricultural imports (from World), whereas over $50 \%$ of the Dutch imports from the UK are final products (mainly not fresh).

Table 2.2 Dutch agricultural exports and imports by category, 2016 (\% of total)

\begin{tabular}{|c|c|c|c|c|c|c|c|c|}
\hline & \multicolumn{4}{|c|}{ Dutch exports to } & \multicolumn{4}{|c|}{ Dutch imports from } \\
\hline & UK & Intra-EU & Extra-EU & World & UK & Intra-EU & Extra-EU & World \\
\hline Propagation materials & 8 & 9 & 12 & 9 & 2 & 4 & 3 & 3 \\
\hline Semi-processed products & 22 & 32 & 30 & 31 & 29 & 35 & 39 & 37 \\
\hline Final products, not fresh & 38 & 33 & 43 & 35 & 52 & 40 & 21 & 31 \\
\hline Total (bn €) & 8.7 & 70.3 & 19.7 & 90.0 & 2.1 & 33.6 & 27.3 & 60.9 \\
\hline
\end{tabular}

Source: EUROSTAT COMEXT; adaptation Wageningen Economic Research.

\footnotetext{
2 Main product groups in these two final product categories are Other edible food products (HS21), meat preparations (HS16), fruit and vegetables preparations (HS19) and Beverages (HS22) as non-fresh final products and Cut flowers (HS0603), vegetables (HS07) and Fruits (HS08) as fresh final products.
} 
Table 2.3 UK agricultural exports and imports by category, 2016 (\% of total)

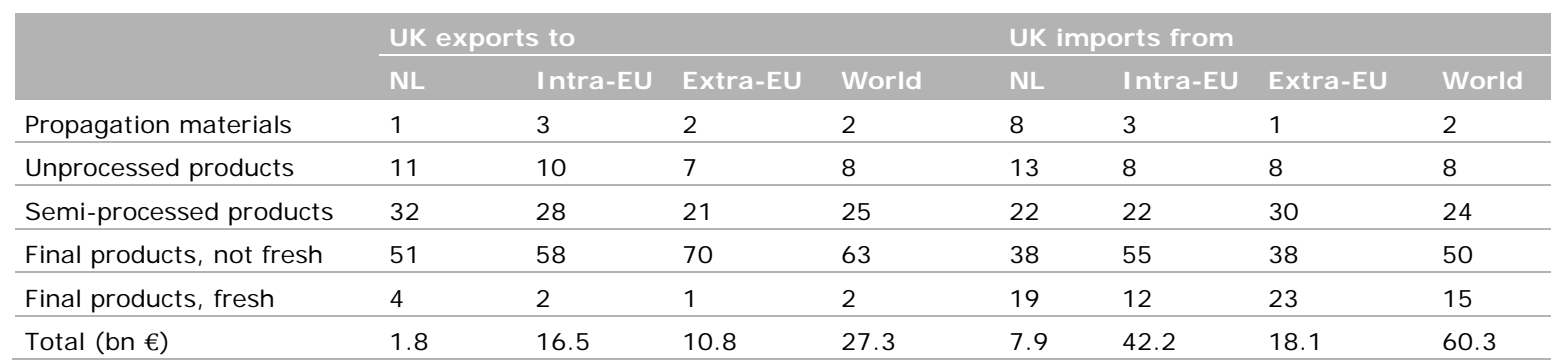

Source: EUROSTAT COMEXT; adaptation Wageningen Economic Research.

Trade in technology embedded agricultural products

In addition to trade in agricultural products, trade flows between the Netherlands and the UK include products that are related to agricultural production, such as fertilisers, pesticides and agricultural machinery. In trade statistics, these so-called technology embedded agricultural products are not counted as agricultural trade, but are classified elsewhere (see for classification of technology embedded products: CBS/Wageningen Economic Research, 2016). In 2016 the value of the exports of these technology embedded agricultural products from the Netherlands to the UK amounted to $€ 450 \mathrm{~m}$ (Table 2.4). This corresponds to about $5 \%$ of the value of the total Dutch agricultural exports to the UK.

Table 2.4 Trade in technology embedded agricultural products, $2016(€ \mathrm{~m})^{3}$

\begin{tabular}{llllll} 
& UK & NL & Intra EU & Extra EU & World \\
Dutch exports to & 450 & - & 4,297 & 3,548 & 7,845 \\
\hline Dutch imports from & 188 & - & 2,100 & 920 & 3,020 \\
\hline UK exports to- & - & 242 & 2,392 & 1,758 & 4,150 \\
\hline UK imports from & - & 422 & 3,433 & 1,119 & 4,552 \\
\hline
\end{tabular}

Source: EUROSTAT COMEXT; adaptation Wageningen Economic Research.

3 In principle the Dutch export value to the UK should have the same value as the UK import from the Netherlands. This table shows it is not. A reason for divergence is, for instance, the use of different definitions of tariff lines (products) or differences in submitting data to the source. However, as all data are from Eurostat, differences in definitions are unlikely to be the cause of differences in export/import data. There may be a few other reasons why trade partners' bilateral flows are valued differently from the exporter's point of view and the importer's view respectively. First, the exchange rates used for converting the national currency into euros (in this case the British pound into euro): Is it done using monthly averages, or annual averages? Second, Eurostat data are regularly updated (preliminary data are re-estimated based on new, updated information). If the timing (and methodology) of national authorities in preparing and submitting the updates to Eurostat differ, the registered export value may differ from registered import value of the same product flow. Third, imports are valued including costs of insurances and freight (cif) and exports without such costs (as 'free-on-board; fob). And, finally, there may be differences between countries in registering the product codes, for instance sometimes countries register trade as 'other' because of privacy or confidentiality reasons. See Eurostat document that explains this trade registration issues in-depth: http://ec. europa. eu/eurostat/documents/3888793/6866187/KS-TC-15-002-ENN.pdf/4232bea9-1fb6-4c3e-ab84-746989ce73ff 


\section{Scenarios definitions and model simulation results}

\subsection{Two Brexit scenarios and a baseline}

In this study the focus is on trade impacts of Brexit on Dutch agricultural products. Two scenarios are considered with respect to trade:

a. EU-UK FTA scenario: The EU and the UK conclude a free trade agreement, say within the two years allowed by Article 50 of the Treaty of the European Union. Note that an FTA is not as advantageous as the free access to the European Single Market that membership of the EU confers. Border arrangements are required to deal with matters like country of origin. However, no tariffs are assumed to be applied in the UK's bilateral trade with the EU. This effectively implies for those products that the UK and the EU are one internal market where products can freely flow. For UK's external trade with third countries, the UK continues to adopt the EU Common Customs Tariff (CCT) on extra-EU trade imports.

b. WTO default scenario: the UK leaves the EU and falls back to the WTO default position, meaning that UK import/export trade falls under the WTO's non-discrimination Most Favoured Nation (MFN) rules. Under this scenario the EU applies its CCT (i.e. the MFN applied rates as agreed in WTO agreements) to UK imports, and the UK applies the same rates set by the EU'S CCT to EU and 3rd party imports. Note that the UK imports are no longer subject to the EU's TRQ import concessions regime. Consequently, the price levels in the UK for products that were imported under that regime are likely to increase (see Section 3.2 below where this assumption and its implications are further explained).

The scenarios differ with respect to the level of transaction or trade facilitation costs (TFCs) ${ }^{4}$ Border procedures are required to deal with all kind of administrative matters like checking the country of origin and export licences. For this reason it is assumed that in the FTA scenario additional transaction costs of trade of $5 \%$ would be incurred (based on Donner Abreu, 2013, and following Boulanger and Philippidis, 2015, and Davis et al., 2017). Under the Default WTO scenario the EU-UK bilateral trade relationship also includes tariffs and levies, implying additional customs formalities and hence additional trade costs. For that reason, under these scenarios a TFC mark-up of 8\% (the upper limit of the average transaction costs, as mentioned in Donner Abreu, 2013) is assumed.

Note that the trade facilitation costs have a tendency to make the UK's imported products (most agricultural products) more expensive and tend to reduce the price of its exported products (cereals, sheep meat, milk powder). See Table 3.1 for a summary of the scenarios. In each of the two trade scenarios the UK is assumed not to establish any trade agreement with other non-EU countries.

The scenarios are compared to a baseline, representing the status quo situation of no Brexit (i.e. the UK remains part of the internal market) scenario.

\footnotetext{
4 Trade facilitation covers all the steps that can be taken to smooth and facilitate the flow of trade. The term has been used widely to cover all sorts of non-tariff barriers, including product testing and impediments to labour mobility, but in the WTO it is defined as 'the simplification and harmonisation of international trade procedures' covering the 'activities, practices and formalities involved in collecting, presenting, communicating and processing data required for the movement of goods in international trade'. The Doha Round talks on trade facilitation cover freedom of transit, fees and formalities related to importing and exporting and transparency of trade regulations - which essentially relates to border procedures such as customs and port procedures, and transport formalities (OECD, 2005). Note that trade facilitation costs are not similar to 'non-tariff measures' trade costs, the latter being associated with divergence of standards and requirements based on, for instance, sanitary and phytosanitary measures, measures to protect human health, etc (see UNCTAD, 2012 for a classification of non-tariff measures).
} 
Table 3.1 Overview of analysed scenarios

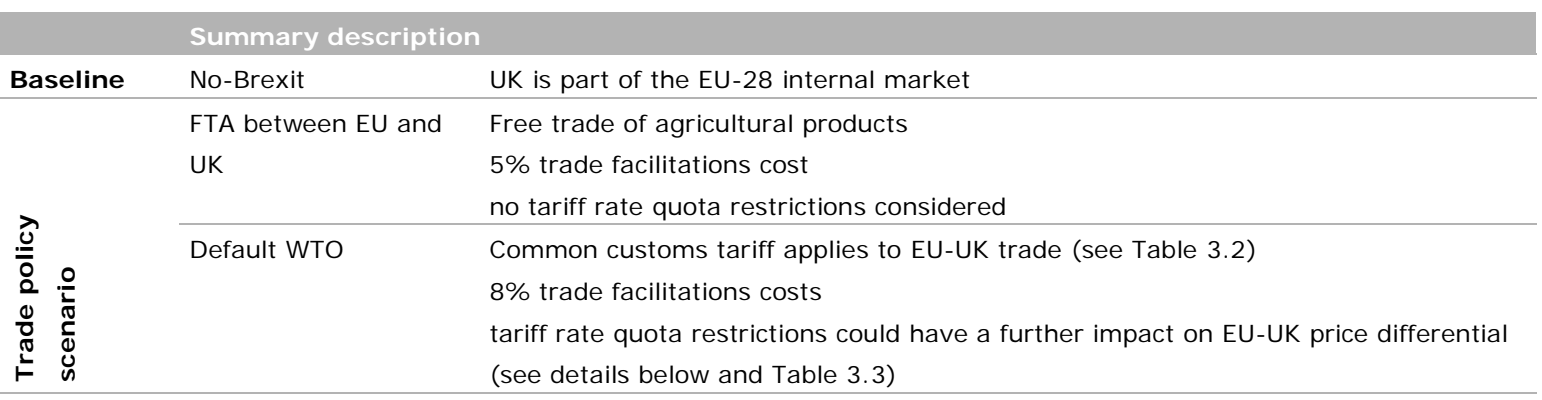

Legend: TFC $=$ trade facilitation costs.

In case no FTA will be reached, the fall back option is the WTO default scenario, where it is assumed that MFN tariffs will be applied to EU-UK trade in agricultural products. It is assumed here that the applied tariffs (including specific tariffs) rather than the (maximum allowed and in most cases higher) bound tariffs will be applied (see Table 3.2 for tariff levels per product). Moreover, a TRQ effect (see details in Table 3.3) and a trade facilitation cost (TFC) effect are accounted for. The imposition of the combination of these three elements (applied tariffs, a TRQ-loss effect and TFCs) will have significant impacts on (both imports and farm-gate) prices and are expected to lead to a decline in bilateral trade between the EU and the UK.

Table 3.2 MFN tariffs implemented in WTO default scenario

\begin{tabular}{|c|c|c|c|c|c|c|}
\hline 1 & 2 & 3 & 4 & 5 & 6 & 7 \\
\hline Sector ${ }^{1}$ & $\begin{array}{l}\text { MFN specific } \\
\text { tariffs } \\
(€ / \text { tonne })^{2}\end{array}$ & $\begin{array}{l}\text { Ad valorem } \\
\text { equivalent } \\
\text { of specific } \\
\text { tariffs }^{3}\end{array}$ & $\begin{array}{l}\text { MFN applied } \\
\text { tariff (ad } \\
\text { valorem) }{ }^{4}\end{array}$ & $\begin{array}{l}\text { MFN applied tariff } \\
\text { (ad valorem } \\
\text { equivalent) }(\%)^{5}\end{array}$ & $\begin{array}{l}\text { TRQ access } \\
\text { loss effect } \\
(\%)^{6}\end{array}$ & $\begin{array}{l}\text { As }(4) \text {, but } \\
\text { including } \\
\text { TFC effect } \\
(\%)^{7}\end{array}$ \\
\hline Wheat & 0 & 0 & 2.2 & 2.2 & 0 & 10.2 \\
\hline Sugar (white) & 339 & 76 & 6.8 & 82.8 & 3.8 & 94.6 \\
\hline Tomato & 0 & 0 & 0 & 0 & 0 & 8 \\
\hline Beef & $12.8 \%+1,768$ & 46.6 & 0 & 46.6 & 0 & 54.6 \\
\hline Sheep meat & $12.8 \%+1,713$ & 40.4 & 0 & 40.4 & 4.2 & 52.6 \\
\hline Pig meat & 536 & 15.8 & 0 & 15.8 & 0 & 23.8 \\
\hline Cheese & 1,671 & 42 & 5.3 & 47.3 & 0.3 & 55.6 \\
\hline SMP & 129 & 4.9 & 0 & 4.9 & 0 & 12.9 \\
\hline WMP & 1,828 & 63 & 0 & 63 & 0 & 71 \\
\hline
\end{tabular}

1) sectors follow the aggregation structure of AGMEMOD (see Appendix 1, Table A1.1). For the determination of tariffs an analysis has been made at detailed tariff lines to select the (weighted) tariffs that are most relevant given the composition of the traded products; 2) Based on trade tariff data base; own analysis. 3) Calculated specific tariff ad valorem equivalents. 4) Ad valorem tariffs. 5) Ad valorem tariff equivalents taking into account specific tariffs and generally applicable ad valorem tariff. 6) Estimates including TRQ effect (see details in Table 3.3 below). 7) Ad valorem tariff equivalent, including TRQ access-loss effect and the cost effect of trade facilitation (leading to $8 \%$ cost increase).

\subsection{Issues with respect to tariff rate quota}

FTAs invariably treat some agricultural products as sensitive, and it is the EU's preferred policy to apply import Tariff Rate Quotas (TRQs) to these products. It is possible that during the EU-UK Brexit negotiations such TRQs are defined. However, given the lack of information on this no such constraints have been considered in the scenario simulations of this study. 
By being a member state of the EU, the UK has access to the EU'S TRQ facility and can import products at the relatively low within-quota tariff rate. The EU has 87 WTO tariff quotas in its commitments as a result of the Uruguay Round Agreement on Agriculture (WTO, 2002). In addition, TRQs frequently form part of an EU FTA. In total, the EU is involved in over 100 TRQ arrangements. How these TRQs might be allocated between the EU27 and a post-Brexit UK has yet to be determined. In October 2017 the EU27 and the UK preliminary agreed to divide existing (import) commitments within the WTO based on historical trade flows, but the proposal was challenged by a group of agricultural exporting countries (FT website). The uncertainty concerns also EU preferential (export) TRQs in third countries that are part of preferential agreements. Since TRQs are not currently allocated by member states (they are allocated on a first-come, first-served basis), the partition of the quotas could be particularly complex (Revell, 2017). Therefore, for simplicity reasons, this study assumes all TRQs will remain fully at the EU27 after Brexit. This assumption implies a maximum price downward effect on EU27 markets and a maximum price upward effect on the UK market: indeed, if TRQs would be split, the EU27 market would absorb less cheap import than assumed in the study's scenarios whereas the UK market would import cheap imports under a TRQ regime.

Given the uncertainty of how TRQs might be split, this study assumes that all TRQs remain fully at the EU27. This implies that, when leaving the EU, the UK's import price of all of its imports (including those volumes that formerly were part of an EU TRQ agreement) will be determined by the over-quota tariff. In case of the WTO default scenario, the loss of the EU'S TRQ facility will (ceteris paribus) lead to an upward pressure on farm gate prices in the UK. This may induce a positive domestic supply response, but is likely to have a negative impact on consumers and can disrupt supply chains that were originally benefitting from this trade concession facility. On the EU market, on the other hand, additional imports will lead to downward price pressure in case all imports the UK previously imported under EU TRQs will find their way to EU27 MS.

A numerical elaboration of the most likely impacts of losing the TRQ and other preferential imports on the UK and EU market requires information on import and domestic price levels, and the share of imported volumes in total supply on the domestic market. The UK currently imports sheep and goat meat, poultry meat, butter, cheese and sugar under a preferential EU-import regime (see Table 3.3). Losing this facility because of a Brexit will result in higher import prices and subsequently a decline of imports, as import conditions for these products change from zero or reduced tariff to MFN import tariffs (equal to EU's CCT in the WTO default scenario). Lower imports are expected to lead to higher UK domestic prices, as domestic demand remains and cannot be satisfied by foreign supply at the (low) prices it used to be imported in pre-Brexit times.

The impact of losing TRQ access on the UK farm gate and consumer prices depends on how much (in terms of volume) of total supply on the UK market is imported and at which prices. The larger the imported volume as a share of total domestic supply and the larger the price wedge between the import and the EU price, the more significant price change is expected as the result of losing the import preferences under the EU trade regimes. Theoretically, the price wedge could be as high as the difference between the EU (domestic) market price and world market price. However, the price wedge may be (much) smaller, because exporters exploit the rent; that is exporters (from non-EU countries) sell into the UK market at a price just below the UK domestic market price. If this is the case in reality, not much will change in the UK's import price after Brexit, and consequently there will be little impact on UK's farm-gate prices.

Table 3.3 below presents the data the study uses to assess the impact on UK's domestic farm prices of losing the preferential imports under EU's trade regimes. For each of the relevant product categories (sheep, poultry, butter, cheese and sugar), we measure the volume of imports under preferential trade regimes (column 2 in Table 3.3) and express these as the share in total domestic supply (production plus net-imports, column 4). We assume that the imported volumes are entering the UK at the world market price (column 5). Domestic production in the UK is valued at an average EU price determined in the AGMEMOD model and based on historical (Eurostat) data. Then, we construct a pooled price (column 7) for domestic production and imports together by using the respective shares in total domestic supply as weights and multiply these with the corresponding prices (column 5 and 
6). The difference between the pooled price and the domestic price is defined as the price depressing effect of the imports (against world market prices) in the original situation (column 8).

Table 3.3 Assessing the price effects on UK markets of losing the preferential import TRQs after Brexit

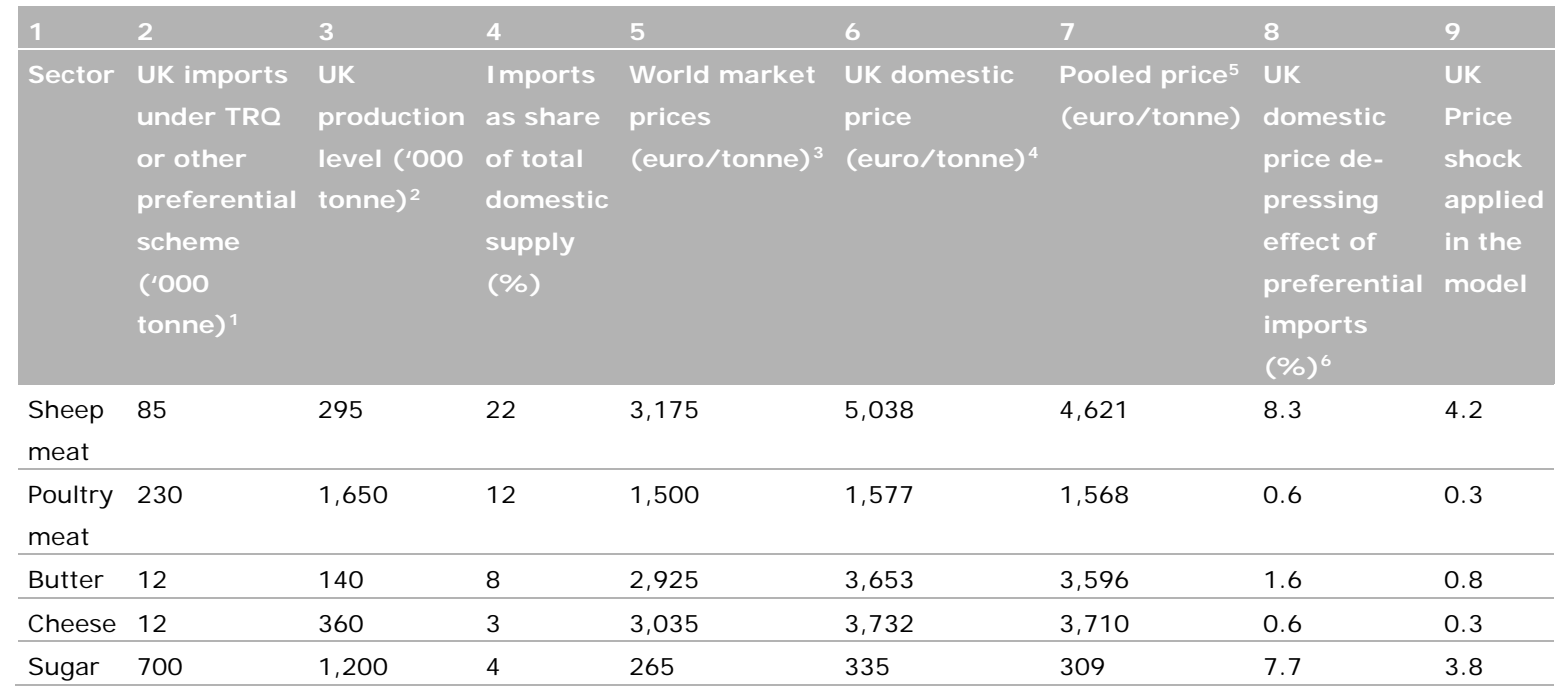

1) Eurostat COMEXT (see also Table 3.1 in Van Berkum et al., 2016 where it is argued that all UK imported volumes of commodities considered benefit from EU's TRQs facilities); 2) from AGMEMOD, average 2013/14; 3) OECD-FAO Agricultural Outlook 2015, average 2013/2014; 4) AGMEMOD, average 2013/14, for sugar: EU threshold price, average 2013/14; 5) pooled price calculated as (price at world market $x$ import share $)+($ UK domestic price $x$ UK production level); 6) (UK farm-gate price minus pooled price)/UK domestic price.

When the UK loses the preferential conditions of importing the observed volumes, its domestic prices will increase by the percentage changes as indicated in column 8 . However, note that when considering import prices against world market prices we assume that all rents accrue to the importers (UK traders and processors). If import prices are higher in practice, the price difference between the domestic and world market price would be less, and hence the calculated price depressing effect would be less. A Brexit would then result in a smaller price shock than indicated by the estimated price depressing effect in column 8 of Table 3.3. Based on an assessment of the TRQ filling rates we made the assumption that the distribution of the rents are likely to be equally divided between importers and exporters (50:50 ratio assumed). That would lead us to implement a price shock that is half the estimated price depressing effect reported in column 8 of Table 3.3: the simulated price increases for sheep and goat meat, poultry meat, butter, cheese and sugar are $+4.2 \%,+0.3 \%,+0.3 \%,+0.8 \%$ and $+3.8 \%$ respectively (column 9 ). Note also that world market prices may highly fluctuate within and over the years, underlining that this estimation is subject to many uncertainties.

\subsection{Static comparative price analysis under the WTO scenario}

Table 3.4 provides a comparative overview of current EU, Dutch and UK domestic market prices as well as (representative) EU import prices (from third countries) for different agricultural products. Next, the table shows the impact of the WTO tariffs on UK import prices and Dutch/EU export prices to the UK in this scenario. The impacts on trade prices are based on current data, with no potential equilibrium adjustments taken into account yet; the latter will be part of the model scenario simulation. This Table 3.4 is used to explain the logical reasoning that will help to understand the model simulation outcomes that follow in the next part of the study.

As a start, current domestic prices of the commodities under consideration are presented in column 2-4 of Table 3.4. Column 2 shows the EU key price: this is the domestic market price in the EU 
country that is the most important market for that commodity. ${ }^{5} \mathrm{~A}$ general rule of thumb is that EU MS with lower than key prices are net exporters on the internal market, whereas MS net importers have higher domestic prices than the EU key price. Column 3 and 4 present UK and Dutch prices. Data show that Dutch prices are lower than EU key prices for sugar, pig and poultry meat, butter and cheese; UK prices are higher than key prices (except for barley) confirming that the country is a netimporter of agricultural products in general. The EU import price (column 5) reflects an average EU border price for imports from third countries. The EU border price is a proxy of the world market price of each of the commodities under consideration.

Table 3.4 A comparative overview of current prices and prices with import tariffs and trade costs included (not yet including market equilibrium price responses); all prices in euro/tonne

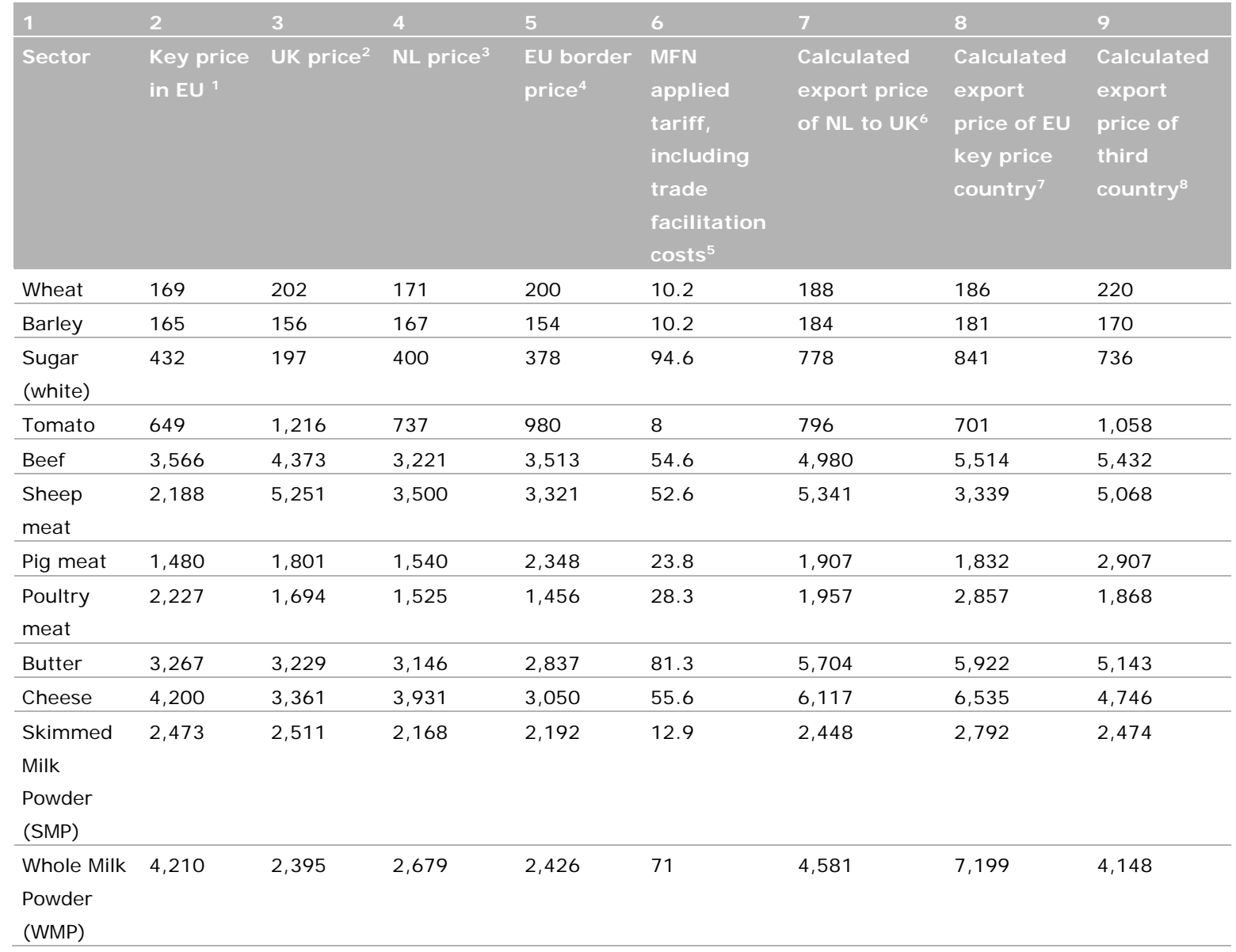

1) EU key country price level used in AGMEMOD, average 2014-2016; 2) UK price level as used in AGMEMOD database, average 2014-2016;

3) Dutch price level as used in AGMEMOD database, average 2014-2016, except for sheep meat and sugar for which estimates are included;

4) EU border price: world market proxy based on EU Medium Term Perspectives; 5) MFN tariff = AVE-tariff (in \% of border price) for WTO scenario as calculated in Table 3.2; 6) Calculated Dutch export price, equivalent to NL price plus WTO tariff and TFCs; 7) EU export price, equivalent to EU key price plus WTO tariff and TFCs; 8) Third country export price equivalent to EU border price plus WTO tariff and TFCs.

\footnotetext{
5 For instance, the price of soft wheat in France is EU's key price for this commodity. In this case, the AGMEMOD country module includes a key price formation equation. This equation is a vector that contains price to which price transmission equations in other country models are linked and it also 'captures' all exogenous variables affecting price formation and the dynamic structure of the AGMEMOD model at the EU combined level. In particular the world market price, price policies (e.g. intervention prices) and trade agreements are included in the key price formation equation, thus indirectly affecting all country prices via price transmission equations. In addition, the key price formation equation may include as a determinant the EU self-sufficiency rate, thus making the key price (and other linked prices) responsive to the EU supply and use balance of the commodity concerned (Chantreuil, Hanrahan and Van Leeuwen, 2012).
} 
As a next step we assume that in a WTO scenario the UK import price level for both EU suppliers and third country suppliers is determined by the EU border price plus the MFN tariff and TFCs, see column 6). ${ }^{6}$ Prices for Dutch exports as well as exports from the EU key price country are based on their respective domestic prices plus the MFN tariffs and TFCs. Results are presented in column 7 and 8. Next, commodity export prices from third (non-EU28) countries are presented in column 9, as the EU border prices including tariffs and TFCs. Where the Dutch export price (column 7) is less than its competitors from the EU (column 8) and non-EU countries (column 9), the Dutch supply is supposed to be most competitive at the UK market after Brexit under this scenario. For these commodities, impacts of Brexit are likely to be small. For those commodities of which Dutch export prices are higher than its competitors, Dutch exports to the UK are expected to be ousted by exports from other EU countries and/or third country competitors.

The comparison of the export price levels in column 7, 8 and 9 as presented in Table 3.4 shows that these are in a rather close range for cereals (wheat and barley), suggesting that no big impacts are likely to occur, whatever the trade scenario. For beef and skimmed milk powder, the Dutch supply is most price competitive, with Dutch export prices for tomato and pig meat rather close to EU competitors, and poultry meat prices close to third country suppliers. Price differences appear most significant for Dutch dairy products such as butter and cheese, commodities that may face serious competition from non-EU suppliers under the WTO scenario. The overall effect on total exports of these respective products depends on opportunities to sell more on alternative markets, either within the EU or outside the Union.

Figure 3.1 below illustrates how the numerical estimations of Dutch, EU and third-country export prices to the UK market may relate to each other when these prices include tariffs and trade costs as under the WTO scenario is assumed. Figure 3.1 only shows results for the Netherlands' most important export products to the UK. Each red column represents the Dutch export price to the UK market. Comparing these red columns with other colours indicates that it would be only beef for which Dutch supply clearly remains price competitive at the UK market. In case of tomato and pig meat, other EU countries would be able to offer somewhat lower prices than the Dutch, whereas for poultry meat and cheese third-country supply would show to be a serious competitor to Dutch supply at the UK market.

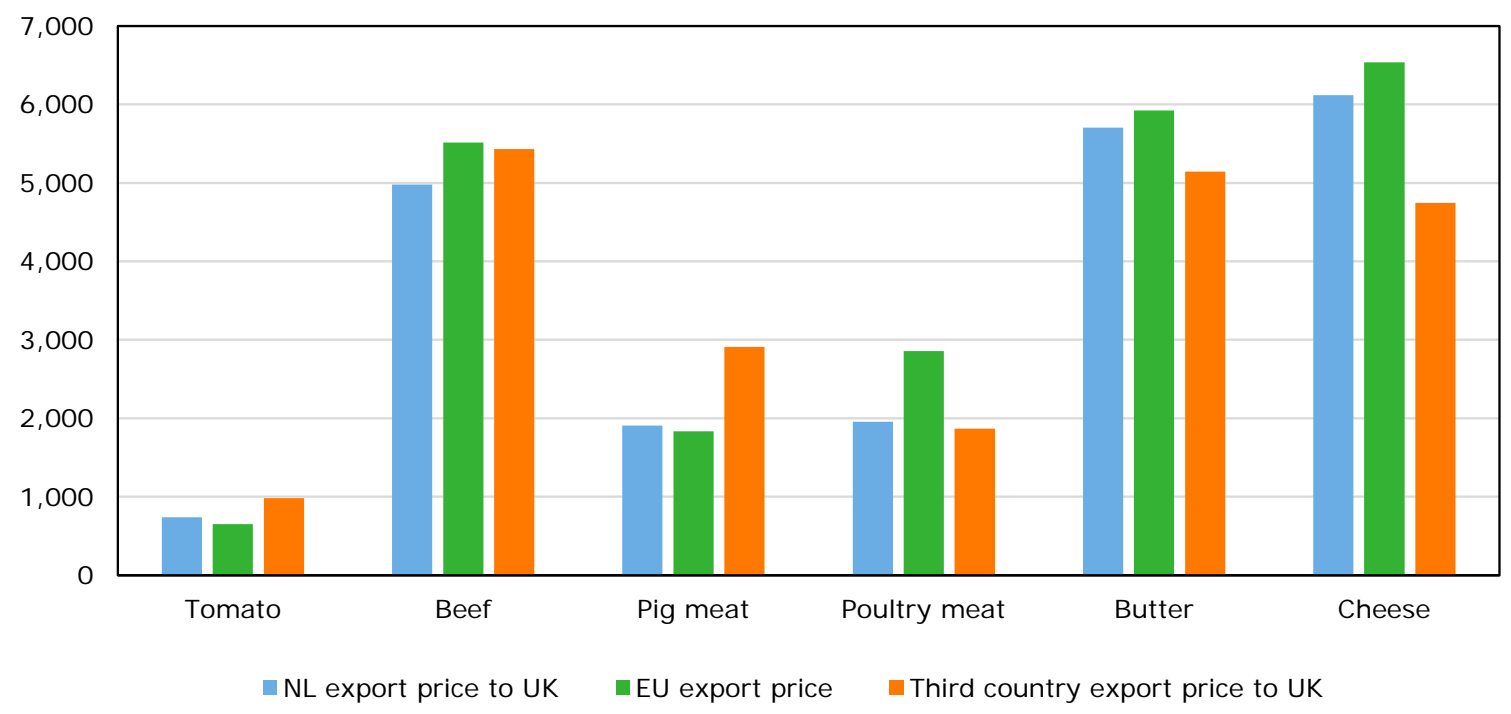

Figure 3.1 Prices at the border of the UK, WTO scenario (euro/tonne)

\footnotetext{
6 Note that this is a simple comparison of (calculated) price levels, taking the existing equilibrium situation as this is generated by the model into account. However, when prices change, due to for example a change in tariffs, supply and demand in all countries included in the model will start to react to this and adjust until a new market equilibrium will result, which also has a unique set of prices. In the calculations in the table above such responses are not accounted for, but only a static analysis is provided.
} 


\subsection{Model results}

\subsubsection{Effects of Brexit scenarios on the UK side}

In short, the argument is that the application of tariffs and trade facilitation costs implies that UK imports become more expensive, which has an upward impact on UK's domestic prices and will lead to less consumption whereas higher prices will stimulate production. Consequently, UK's import needs will go down. Table 3.5 presents the estimated price and production changes that are the result of the dynamic market responses that follow the introduction of the FTA scenario assumptions (most notably the introduction of trade facilitation costs) and the WTO scenario assumptions (tariffs and trade facilitation costs) respectively. Figures indicates that production changes are very modest in the FTA scenario, with the note that the additional milk produced is mainly processed into powder. This trend is reinforced in the WTO scenario, where price changes are much more significant for all products, with consequent impacts on production.

Table 3.5 Estimated changes (in \%) of prices and production in the UK, FTA and WTO scenario (2025, \% changes compared to baseline, rounded figures)

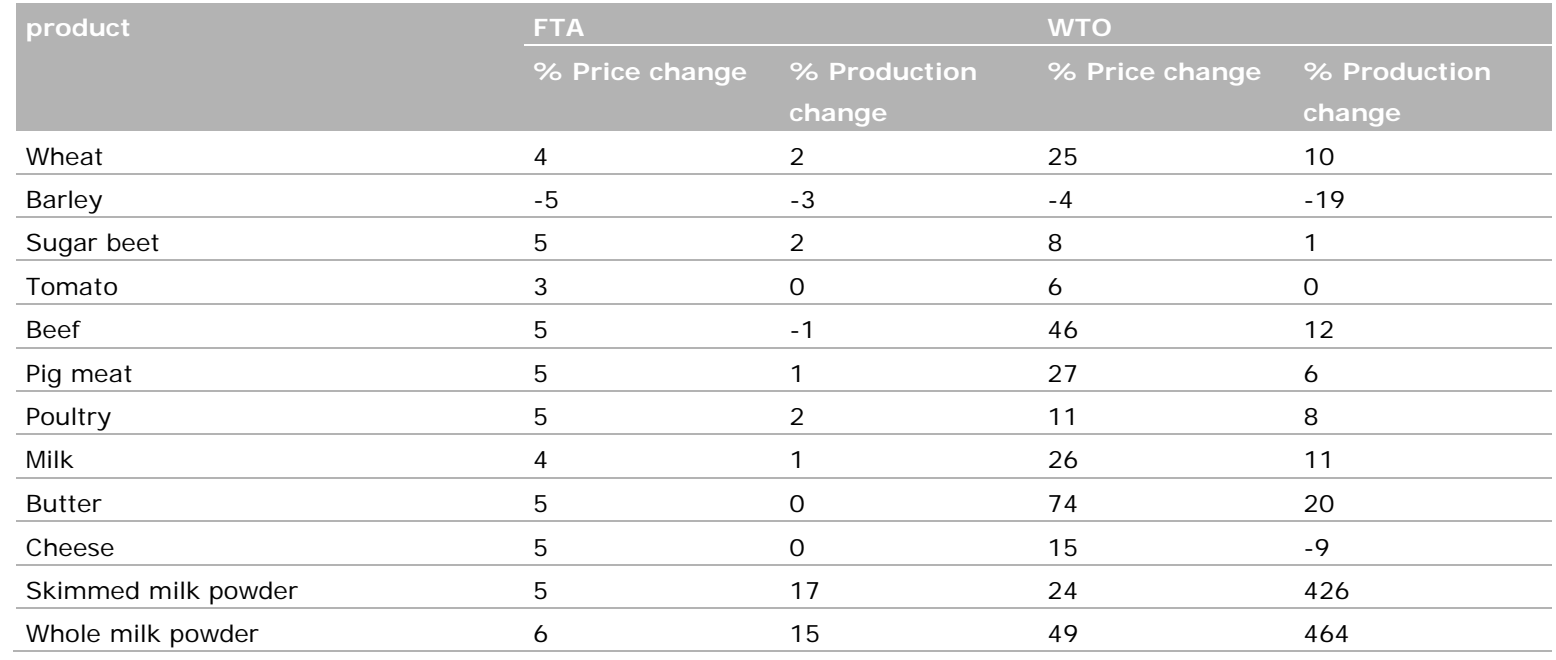

Source: authors' calculations.

The stylised argument above is further elaborated in Figure 3.2 in which projected changes in imports of the UK under the two Brexit scenarios are presented. Not surprisingly, impacts of an FTA on UK imports are rather small, with the largest import reduction impact $(-12 \%)$ for whole milk powder (WMP). The model estimates further show that in a WTO scenario in relative terms UK imports WMP fall strongest, followed by butter and beef imports. Other imports of the selected products will decline as well except for cheese imports. In case of cheese, the increased imports are explained by the fact that currently UK's domestically produced milk is largely processed into other products than cheese, as these products (butter and powder) are more attractive to processors. Table 3.5 above indicates that especially in the WTO scenario UK dairy price increases will be most significant for butter and powder, and will stimulate processors to process additional milk produced after Brexit into these products with the effect that the production of cheese even declines (despite price increases of $15 \%$ compared to the baseline situation). ${ }^{7}$

\footnotetext{
7 Note that where price changes are relatively high (as is the case in the WTO scenario), the projected production responses can only occur if investments in expanding the production capacity take place. This assumes that farmers are able to make such investments which will bring returns only in the medium to longer term. Given the current performances in the sector and some of its characteristics (an aging farmers' community, relatively high production costs, livestock sector highly dependent on direct income payments (see e.g. Van Berkum et al., 2016), expanding production capacities may be an option to only part of the UK farming community.
} 


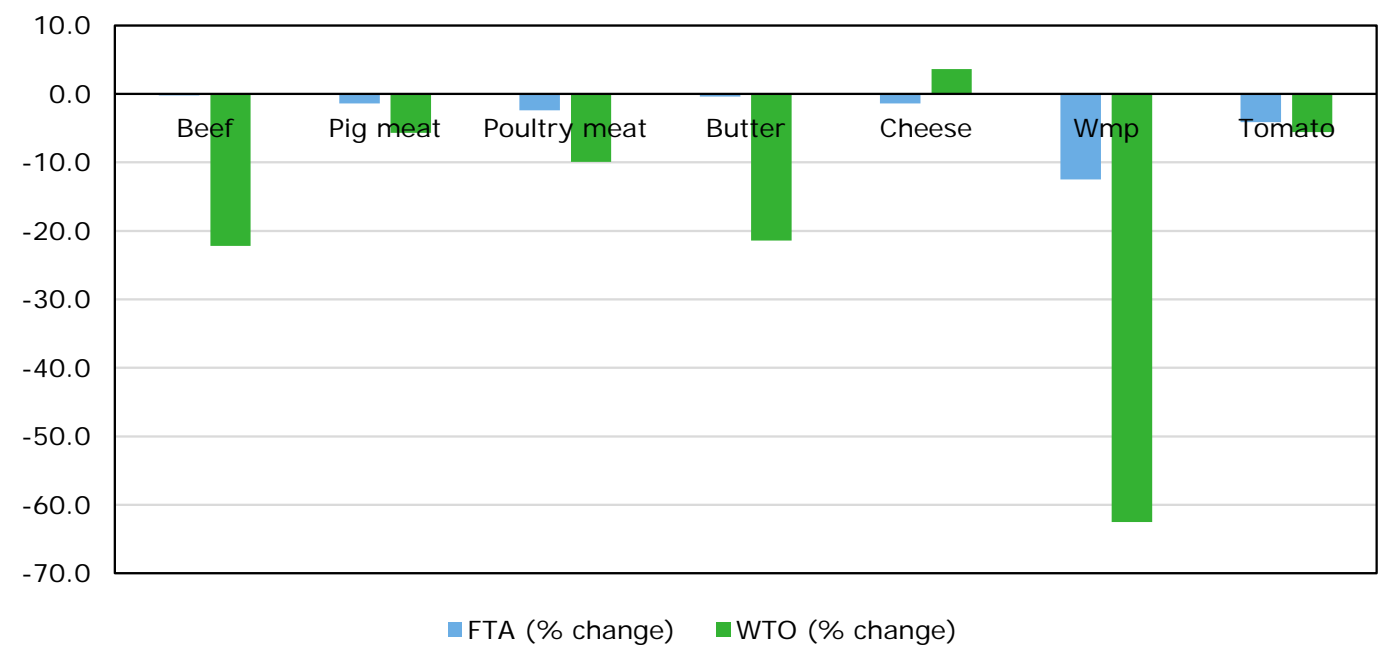

Figure 3.2 UK import changes compared to baseline, 2025 (\% change)

The relative changes in UK's imports have to be put in context by adding the absolute numbers of changes in imports, which is done in Table 3.6 below. In absolute terms, the decline in imports of beef is most significant, followed by poultry meat.

Table 3.6 Change UK imports under the FTA and WTO scenario, in 1,000 tonnes (compared to baseline, estimates of levels in 2025)

\begin{tabular}{llllllll} 
Product & Beef & Pig meat & Poultry meat & Butter & Cheese & WMP & Tomato \\
FTA scenario & -1 & -10 & -20 & -1 & -6 & -6 & 18 \\
\hline WTO scenario & -106 & -42 & -77 & -34 & 16 & -40 & -23 \\
\hline
\end{tabular}

Source: authors' model estimations.

Next, the changes in UK imports under a WTO scenario (as the most 'extreme' scenario) are put in context of the EU27 production levels to indicate the weight the changes in imports may have on the EU market, knowing that UK imports the commodities under consideration mainly from other EU countries. The numbers in Table 3.7 below - all in million tonnes - show that UK import changes are very small compared to the size of the EU27 market for these commodities.

Table 3.7 EU27 production levels of meat, dairy products and tomato (in million tonnes)

\begin{tabular}{llllllll} 
Product & Beef & Pig meat & Poultry meat & Butter & Cheese & WMP & Tomato \\
EU27 production level & 6.9 & 22.5 & 12.6 & 2.2 & 9.2 & 2.3 & 11.8 \\
\hline
\end{tabular}

Source: Eurostat, Statistics explained, agricultural production.

\subsubsection{Effects on Dutch exports and production value}

These changes in UK import needs affect Dutch export flows to the UK. Projected changes in Dutch exports are presented in Figure 3.3 and 3.4. The graphs show the effects on Dutch total exports and on the Dutch-UK bilateral exports of the most important products in Dutch agricultural trade with the UK for the FTA and the WTO scenario, respectively.

Given that under the FTA scenario Dutch export price changes will be relatively small (only caused by increasing trade facilitation costs of $5 \%$ in its trade with the UK plus the impact of UK's losing trade preferences under TRQ regimes for some products), Dutch exports to the UK and the rest of the world will be affected only marginally. Indeed, UK import and farmers prices will be little affected (see Table 3.5 above) and hence the country's import needs will not change much. Also, recall that in this 
scenario competition Dutch commodities face at the UK market from non-EU countries remain unchanged as the UK and EU27 continue to adopt the EU MFN tariffs on extra-EU imports.

Figure 3.3 indicates that consequences of the FTA scenario on Dutch exports to the UK turn out to be Particularly small for all five products presented in the figure, with only for beef $(-0.1 \%)$ and poultry meat $(+0.1 \%)$ a noticeable yet very little effect. This shows that under this scenario, in which trade with the UK remains rather undistorted and external tariffs on imports from non-EU countries are in place, Dutch exports in agricultural products are as good as not affected.

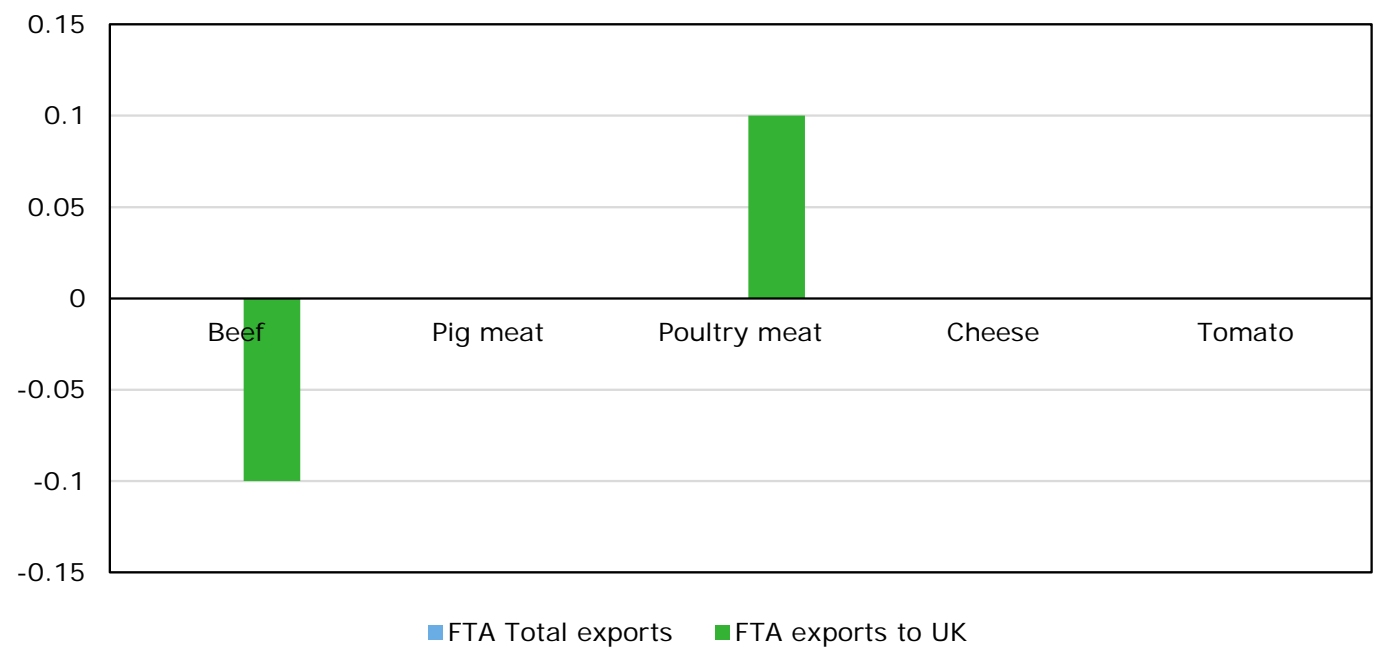

Figure 3.3 Projected \% changes in Dutch exports, FTA scenario (2025, compared to baseline)

A WTO scenario, though, has much more significant impacts on the Dutch agricultural exports to the UK than an FTA scenario. In the WTO scenario, tariffs add a the wedge to the Dutch export prices that reduces its competitiveness at the UK market, with consequences for at least part of its exports to the UK and, most likely, for its total export performance as well. Not only Dutch exports will face more difficulties to enter the UK market, also other EU Member States will face similar barriers. After all, additional barriers to the UK market will imply pressures imposed on the EU price level. Note that this downward pressure on prices will generate a cost to all EU Member States as it lowers the total value of production, even irrespective of changes in trade flows. Another impact of the tariff wedge is that prices in the UK will increase - the extent of the increase depends on the magnitude of the tariff - and will reduce UK imports (as the UK's home production will increase and its domestic demand will decrease).

Figure 3.4 summarises the effects of a WTO scenario on Dutch exports to the UK. Strongest percentage changes appear in Dutch exports of pig meat $(+7.9 \%)$, poultry meat $(-3.6)$ and cheese ($18.2 \%)$. The overall trade effect of a WTO scenario is rather small, indicating that the impact of a WTO scenario is largely on the Dutch-UK bilateral trade (and how Dutch exports reallocate among other markets), whereas the overall effects on exports is only marginally. ${ }^{8}$

\footnotetext{
8 This is explained by the fact that the WTO scenario (and the FTA scenario as well) has little impact on world market prices, which is one of the factors changing EU prices. If UK leaves the EU, UK's next export position will be part of the 'Rest of World'. As this is only a small fraction (from a UK perspective), impacts on world market prices are very small, and consequences for the EU key price minimal (see footnote 5 for the explanation of the EU key price). The largest shock on EU key prices is caused by changes in the self-sufficiency rates (in the EU key-price country) due to the UK leaving the EU. The changes in the self-sufficiency ratios in EU countries are rather modest. This is not unexpected given that the size of the changes of UK imports under the 'pessimistic' WTO scenario is very small compared to the EU27 market as a whole for each of the products under consideration (see Table 3.7).
} 


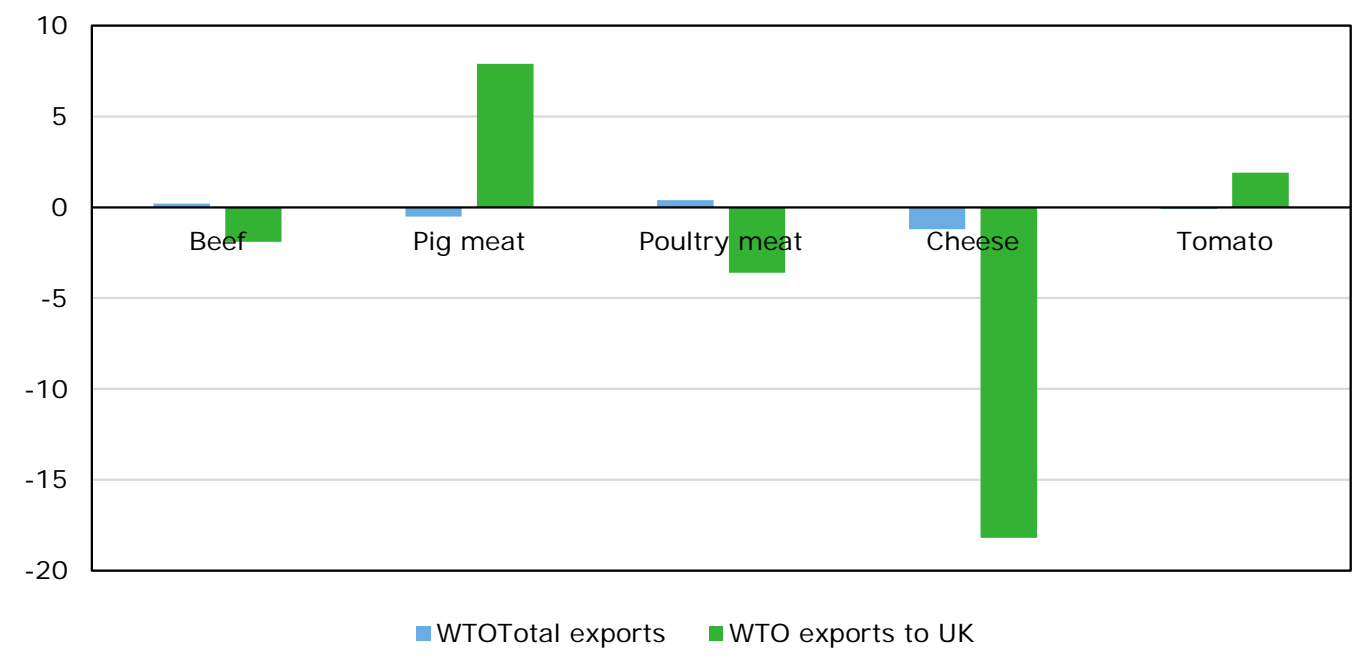

Figure 3.4 Changes in Dutch exports according WTO scenario, 2025 (\% changes compared to baseline scenario)

These projections of trade effects of the WTO scenario are the result of market dynamics created by higher UK import prices (caused by assumed facilitation costs plus the introduction of import tariffs under this scenario) and response to these changed import prices by exporters to the UK. How these higher UK import prices will affect the Dutch agricultural sector or any other foreign supplier of UK imports depends on the importance of the UK market for the Dutch (or any other foreign) suppliers, the price pressure on the domestic market that is the result of the additional barriers to trade with the UK and the self-sufficiency rate (that is, the supply-demand ratio) on each country's market (with netexporting countries with a higher self-sufficiency rate facing more price pressure than net-importing countries). Therefore, production in EU countries that are currently the UK's main suppliers of agrifood products does not equally respond to trade barriers that result from Brexit. This feature is captured by the AGMEMOD model, in which price elasticities of supply (and demand) are (econometrically) estimated or calibrated on past trends in each of the EU member states (See Appendix 4 for an explanation of elasticities used). Those trends indicate that, for instance, pig meat production in Spain is much more responsive to prices than in the Netherlands, causing a significant downward production effect in Spain as the result of the price pressure at the EU27 market due to Brexit. Less production leads to (much) less exports, which leaves room to other competitive suppliers to take over market share. As Figure 3.4 indicates, the Dutch pig meat sector seems to benefit from this dynamics by being able to export more to the UK under the WTO scenario, although at the same time UK's imports of pig meat decline a bit (9,000 tonnes, see Table 3.5 above) ${ }^{9}$ A similar market dynamics (in which Spain's production and exports respond more than proportionally to price changes) allows the Dutch tomato exports to the UK to grow after Brexit, although UK's imports are projected to decline.

As Figure 3.4 shows only relative changes, the percentage changes should be considered in absolute terms as well for a balanced evaluation of impacts. Table 3.8 below presents these absolute figures and compares these with the average Dutch exports in 2014-2016. This overview shows that impacts of a WTO scenario on Dutch exports are generally small for all products included in this overview.

\footnotetext{
9 As explained in Appendix 1, AGMEMOD is a net-trade model and for the purpose of this study, Dutch exports and imports have been disaggregated in order to unravel UK-Dutch export and import flow. Other EU MS net-trade relations have not been disentangled, implying that for other MS than the Netherlands no bilateral trade impacts can be shown.
} 
Table 3.8 Changes in total Dutch exports and in Dutch exports to the UK in absolute terms, in 2025 according to WTO scenario compared to baseline scenario, and the average annual export level (average of 2014-2016 levels) (1,000 tonnes)

\begin{tabular}{|c|c|c|c|c|}
\hline & $\begin{array}{l}\text { Change in NL total } \\
\text { exports to } \text { world }^{1 \text { ) }}\end{array}$ & $\begin{array}{l}\text { Change in NL export } \\
\text { to } \mathrm{UK}^{1)}\end{array}$ & $\begin{array}{l}\text { NL total exports, } \\
2014-2016^{2)}\end{array}$ & $\begin{array}{l}\text { NL exports to UK, } \\
2014-2016^{21}\end{array}$ \\
\hline Beef & 0.8 & -0.8 & 490 & 45 \\
\hline Poultry meat & 4.1 & -8.2 & 1330 & 200 \\
\hline Cheese & -7.4 & -9.5 & 780 & 30 \\
\hline
\end{tabular}

Source: 1) AGMEMOD model simulations; 2) AGMEMOD database (rounded figures).

Effects on Dutch trade flows may be modest, yet for a more complete picture we also analyse the impacts of Brexit on production values, as an indicator of revenues forgone because of Brexit. For most products, farm gate prices in the Netherlands are depressed as a consequence of the EU becoming more self-sufficient because access to the UK - an important importer of food and agricultural products becomes more difficult under the WTO scenario. Lower prices will result in lower production levels. Less production and lower prices implies lower sector production values and less profits if lower revenues are not compensated by lower costs of production. Table 3.9 below shows the extent production values of selected products are affected by Brexit under the WTO scenario. ${ }^{10}$ All products show a negative sign, with poultry, pig meat and cheese production values showing the most significant decrease. Added up, production value foregone in these five sectors is about $€ 125 \mathrm{~m}$. These five sectors account for roughly $25 \%$ of the total production value of the Dutch agricultural and horticultural sector. Assuming that all sector would face a similar price depressing effect as those that we have discussed here, total production value foregone for the whole sector would be approximately $€ 500 \mathrm{~m}$. Compared to an overall production value of the primary sector of $€ 27 \mathrm{bn}$ in 2016 (Wageningen Economic Research, Agrimatie website), the production value foregone is an estimated $1.8 \%$.

Table 3.9 Impact on prices and production volumes in the Netherlands (\% change)

\begin{tabular}{lllll} 
Sector & $\begin{array}{l}\text { Price change } \\
(\%)\end{array}$ & $\begin{array}{l}\text { Production volume } \\
\text { change }(\%)\end{array}$ & $\begin{array}{l}\text { Change in Production } \\
\text { Value }(\%)\end{array}$ & $\begin{array}{l}\text { Production value loss } \\
(€ 1,000)\end{array}$ \\
\hline Tomato & -0.9 & -0.1 & -1.0 & 7.4 \\
\hline Beef & -2.0 & 0.1 & -1.9 & 26.3 \\
\hline Pig meat & -0.8 & -0.4 & -1.2 & 28.4 \\
\hline Poultry meat & -3.3 & 0.1 & -3.2 & 30.1 \\
\hline Cheese & -1.4 & -0.9 & -2.3 & 29.3 \\
\hline
\end{tabular}

Source: AGMEMOD model simulations.

\subsubsection{Summarised outcomes and qualifications of model simulation results}

Outcomes summarised

The outcomes of the model projections can be summarised as follows:

- Trade effects of a FTA are minor both in terms of the Dutch bilateral trade with the UK as well as for the Dutch total exports of agricultural products

- Impacts of a WTO scenario on Dutch exports are featured by reallocation of exports between the UK, other EU MS and third countries. This scenario shows:

- High UK import (ad valorem plus specific) tariffs on beef, butter and cheese

- Less import needs of the UK

- Declining Dutch exports to the UK for beef, poultry and cheese, yet increasing export volumes for pig meat and for tomato

- In volume terms, modest impacts on Dutch exports

\footnotetext{
${ }^{10}$ Note that effects on commodity prices and hence on the overall production, consumption and net trade in the FTA scenario are negligible.
} 
- An overall effect on production values foregone by Brexit of 3.3\% for poultry, $2.3 \%$ for cheese, close to $2.0 \%$ for beef and around $1 \%$ for pig meat and the tomato sector.

Outcomes qualified by model drawbacks

As indicated in the introduction, our scenario results are highly dependent on the features of the model used and assumptions underlying the projections. Moreover, model calculations have a number of drawbacks, that need to be taken into account for a proper understanding of the outcomes.

An important feature of AGMEMOD is that its projections are price-driven. This does not reflect the real world in which trade is based on quality differences or product differentiation. Moreover, this model feature disregards market segmentation as sales strategy (by selling products with specific features to specific markets or target groups, like meat exporters do to maximise the value of the whole carcass: 'vierkantsverwaarding' in Dutch). In all Dutch subsectors one may find suppliers of 'bulk' commodities next to those who offer products to a high quality segment of the market or who exploit other product attributes than price and/or quality. For instance, the Dutch (semi) hard cheese exported to the UK taste rather different from the soft cheeses or cheddar type of cheeses exported by most other EU countries to the UK, and is appealing to a certain British consumer that values this type of cheese. Due to its characteristics, its market position may be less affected by price changes due to Brexit than the model results suggest. Moreover, some of the Dutch products are rather unique, with little or no substitutes. Examples are Dutch flower bulbs and some sorts of propagation material, which are within a certain price range not that sensitive to price changes. The Dutch supply of fresh fruits and vegetables often includes a highly efficient logistic concept, and this combination of product and service may also act as a competitive strength. All in all, these characteristics of Dutch exports point at the fact that Dutch agricultural export flows are determined by other factors than price levels only. The model results do not take these other factors into account.

I mpacts of non-tariff measures

The model simulations do not include possible impacts of diverting non-tariff measures on trade costs. The UK government, though, may request quality and/or food safety conditions to imports that are different from the current EU trade conditions. Whether the UK will do so is yet unknown, and hence provides an enormous uncertainty to the businesses engaged in trade with the UK. ${ }^{11}$ In interviews with industry representatives, much concern is raised about how the UK will design its trade standards with regard to food safety, quality, phytosanitary and veterinary requirements after Brexit (see Appendix 2 for short summaries of the interviews held). In any trade relationship after Brexit, more frequent and stringent trade inspections are expected compared to the current situation with the UK being part of the internal market. This will bring substantial costs in terms of extra labour and administrative costs, next to additional waiting time at the border, which may have negative consequences for the quality of fresh products in particular. Digitalisation and automation of procedures and open communication platforms that can help to identify possible upcoming trade distorting issues are among the options the agrofood sector representatives suggest in order to save time and costs of trade with the UK in post-Brexit times. The main issues highlighted by the interviewees are summarised as follows:

- Brexit will always imply additional costs compared to the current situation, whatever trade arrangements will be made after Brexit. How much these costs will be depends on the details of the arrangement

- Even in case trade rules and conditions remain unchanged on paper, Dutch exporters fear interpretation of these rules may differ, which may lead to additional costs anyway;

- Additional documents and additional inspections will imply the involvement of more human capacity (extra labour costs) and infrastructures (physical border, data systems etc.) and time (e.g. waiting at the border);

- Disapproval of cargo at the border implies high costs as products have to be shipped back and/or alternative markets have to be found.

11 KPMG (2018) made cost estimations of additional general border formalities and sector specific market access requirements in case the UK is a third country. Two case studies refer to agrifood: meat and cut flowers. Cost are estimated to be $0.7-1.9 \%$ of the total trade value (imports and exports) of meat between the Netherlands and the UK. For cut flowers, the additional costs range between 0.8 and $1.3 \%$ of the trade value. Note that while these costs are indicated as costs of non-tariff trade barriers, most costs calculated in this study are trade facilitation costs (see for the definition foot note in Section 3.1). 


\section{Conclusions}

In this study we examine the impacts on Dutch agricultural exports of two alternative Brexit scenarios using a partial equilibrium modelling framework. In particular we consider a Free Trade Agreement and a WTO default scenario, comparing results for 2025 with a baseline assuming the UK remains an EU MS.

An FTA scenario implies zero tariffs and 5\% trade facilitation (transaction) cost, whereas in a WTO scenario the UK applies EU's bounded MFN tariffs.

Of course, model projections are highly dependent on the model assumptions and its features, not the least reflected by its price elasticities of supply and demand determining the responsiveness of production, consumption and trade to changes in prices. These elasticities are based on historical data, whereas some of the projected price changes within the scenario analysis (especially in the WTO scenario) go beyond the range of variation experienced historically. Thus, there is some added uncertainty associated with our projections of the extent to which production, consumption and trade might react under such circumstances. Moreover, costs of trade caused by regulatory divergence have only been taken into account by assumption, without much detailed reflection on how trade arrangements on this area may form. Moreover, model results may be affected by how the UK agricultural sector may respond (would the sector be able investing in expanding its production capacities? In case of restrictions on migrant labour, can subsectors now heavily dependent on foreigners mitigate the potential negative impacts on their operations?), ${ }^{12}$ by the assumed agricultural support policy in place (the model simulations assume a continuation of CAP-like direct payments in the UK after Brexit) and by general economic developments affecting income, inflation ${ }^{13}$ and exchange rate, which eventually all may affect Dutch export opportunities under whatever trade arrangement with the UK. Nevertheless, the results indicate the broad directions of change in Dutch export flows to the UK within each trade scenario projected. A last note is that the scenarios designed in this study assume that the UK does not establish any trade agreement with other non-EU countries. If the UK will do so, the EU27 (including the Netherlands) may expect increasing competition at the UK market from non-EU countries for the products subject to such preferential agreements.

In case of a FTA scenario model projections show insignificant effects on the Dutch bilateral trade flows with the UK. A WTO scenario, on the other hand, implies additional trade costs and import tariffs, of which the latter are relatively high for beef, butter and cheese. This leads in the first place to less import needs of the UK, which affects Dutch exports to the UK negatively for beef, poultry and cheese in particular, whereas exports of pig meat and tomato increase somewhat. In absolute terms, impacts on Dutch exports are modest. Overall, the effects on production values foregone by Brexit are $3.3 \%$ for poultry, $2.3 \%$ for cheese, close to $2 \%$ for pig meat and beef and $1 \%$ for tomato. These effects are dominated by the price depressing effect on Dutch and other EU countries' domestic markets that follows Brexit.

\footnotetext{
12 The migrant labour issue is extremely important to UK's fruit and vegetable sector. The growers organisation English Apples and Pears has indicated to need more than 10,000 seasonal pickers to harvest the fruits with a large majority coming from the EU. Without access to those workers the organisation says that the country's 300,000 tonne fruit crop worth GBP180m would be at risk (www. brexitfoodandfarming, November 2017). Other subsectors, such as the meat (slaughter) sector also depend strongly foreign labour, as well as the food retail, restaurants/bars and food transport.

${ }^{13}$ Cost of food in the United Kingdom increased 4\% in October of 2017 over the same month in the previous year https://tradingeconomics.com/united-kingdom/food-inflation).
} 


\section{References and websites}

Banse, M. and F. Freund (2017). Mögliche Auswirkungen eines Brexit auf den deutschen Agrarhandel; Braunschweig, Thünen-Institut für Marktanalyse, Thünen Working Paper 70

Bellora, C., Emlinger, C., Fouré, J. and Guimbard, H. (2017). Research for AGRI Committee, EU - UK agricultural trade: state of play and possible impacts of Brexit, European Parliament, Policy Department for Structural and Cohesion Policies, Brussels

Boulanger, P. and G. Philippidis. The End of a Romance? A Note on the Quantitative Impacts of a 'Brexit' from the EUJ ournal of Agricultural Economics, Vol. 66, No. 3, 2015, 832-842 doi: $10.1111 / 1477-9552.12120$

Centraal Bureau voor de Statistiek en Wageningen Economic Research (2016). Richting een toekomstbestendige agribusiness. Kwantitatieve voorbeelden op het gebied van landbouwkennis, innovatie, -technologie en - duurzaamheid. CBS, Den Haag

Ciuriak, D., A. Dadkhah and J. Xiao (2017). Brexit Trade Impacts: Alternative Scenarios; Purdue, USA, Contributed paper at the 20th Annual Conference on Global Economic Analysis, 7-9th J une 2017

Davis, J., S. Feng, M. Patton and J. Binfield (2017). Impacts of alternation post-Brexit trade agreement on UK agriculture: sector analysis using the FAPRI-IK model. August 2017. https://content17.green17creative.com/media/99/files/FAPRI_UK_Brexit_Report.pdf

Donnellan, T. and K. Hanrahan (2016). Brexit; Potential Implications for the I rish Agri-Food Sector; Athenry, Teagasc

Donner Abreu, M. (2013). Preferential rules of origin in Regional Trade Agreements. World Trade Organization, Economic Research and Statistics Division. https://www.wto.org/english/res_e/reser_e/ersd201305_e.pdf

Emerson, M., M. Busse, M. Di Salvo, D. Gros and J. Pelkmans (2017). An assessment of the economic impact of Brexit on the EU27; Brussels, European Parliament, Directorate General for Internal Policies, Policy Department A: Economic and Scientific Policy

FT website. (Financial Times, 16 October 2017). Mind your TRQs: a Brexit lesson in global trade. https: //www. ft. com/content/ 1aa06e64-b24f-11e7-a398-73d59db9e399

Freund, F., M. Banse, F. Offermann, J. Pelikan and P. Salamon (2017). The UK after the Referendum: Renegotiating Tariffs and Beyond; Purdue, USA, Contributed paper at the 20th Annual Conference on Global Economic Analysis, 7-9th June 2017

Jafari, Y. and W. Britz (2017). Brexit - an economy-wide Impact Assessment looking into trade, immigration, and Foreign Direct Investment; Purdue, USA, Contributed paper at the 20th Annual Conference on Global Economic Analysis, 7-9th J une 2017

KPMG (2018). Impact van non-tarifaire handelsbelemmeringen als gevolg van Brexit. Ministerie van Economische Zaken en Klimaat, Ministerie van Landbouw, Natuur en Voedselkwaliteit, referentie:A1700012187.D5

Lang, T., E. Milestone and T. Marsden (2017). A Food Brexit: time to get real; A Brexit briefing; London, Sussex and Cardiff 
OECD (2005). The costs and benefits of trade facilitation. OECD Observer, October

Revell, B.J . (2017). Brexit and Tariff Rate Quotas on EU Imports: A Complex Problem. EuroChoices vol. 16, issue 2, August 2017, pp 10-17.

Rojas-Romagosa, H. (2016). Trade effects of Brexit for the Netherlands; The Hague, CPB Netherlands Bureau for Economic Policy Analysis, CPB Background Document, June 2016

Van Berkum, S. (2012). International perspective. Present position of and opportunities for the Dutch agribusiness at international markets (in Dutch). Background report to a Round table Internationalisation of the Topsector Agr\&Food, 7 September 2012.

Van Berkum, S., J ongeneel, R., Vrolijk, H., Van Leeuwen, M., Jager, J. (2016). Implications of a UK exit from the EU for British agriculture. The Hague, LEI-Wageningen UR (study for the National Farmers' Union (NFU), Warwickshire, UK). LEI Report 2016-046.

Vanzetti, D. (2017). Brexit: Implications for agricultural exporters; Purdue, USA, Contributed paper at the 20th Annual Conference on Global Economic Analysis, 7-9th J une 2017

Yu, W., C. Elleby, K.M.H. Lind and M.N. Thomsen (2017). Modeling the potential impacts of two BREXIT scenarios on the Danish agricultural sectors; Copenhagen, University of Copenhagen, IFRO Report 260

WTO (2002). Market access. Tariffs and tariff quotas. Agriculture negotiations: backgrounder. https://www.wto.org/english/tratop_e/agric_e/negs_bkgrnd10_access_e.htm 


\section{Appendix 1 AGMEMOD: description of the model}

Many studies quantifying the economic impacts of Brexit use the general equilibrium model GTAP (Banse and Freund, 2017; Ciurak et al., 2017; Freund et al., 2017; Jafari and Britz, 2017; RojasRomagosa, 2016; Vanzetti, 2017; Yu et al., 2017). A drawback of this model is the use of rather a aggregated level of the agricultural sector. In order to take account of individual agricultural products, and in particular agricultural products that are relevant in the Dutch agricultural trade flows, we use the partial equilibrium model AGMEMOD in this study.

\section{Scenario analyses on sector level}

In order to quantify the possible outcomes of the scenarios identified Wageningen Economic Research will use the AGMEMOD model. AGMEMOD is a dynamic, multi-country, multi-market, partial equilibrium model. It provides significant detail on the main agricultural and its processing sectors for all EU Member States and some EU neighbours. The model has been largely econometrically estimated at the individual Member State level although in some cases, when estimation was either not feasible or meaningful, model parameters have been calibrated (Chantreuil, Hanrahan and van Leeuwen, 2012). The model is extensively used for the analysis of the EU Common Agricultural Policy (CAP) at Member State level (see for example Erjavec et al. (2011), Salputra et al. (2011) and Bartova, Fellmann and M'barek (2009) as well as for baseline projections (Offermann et al., 2014). Moreover, Wageningen Economic Research has used the AGMEMOD model in a study on implications of an UK exit for the British agriculture conducted for the National Farmers Union in April 2016 (Van Berkum et al., 2016).

The model has been developed and is currently maintained by the AGMEMOD consortium. It includes the expertise of an extensive network of economists collaborating across the EU. This growing network brought together a level of pan-national expertise that would have been difficult to assemble otherwise. The activities of the experts are supplemented by the assistance of national experts in commodity markets in individual countries, who frequently review the models and projections produced by the national modelling teams (Salamon et al., 2008).

Data requirements for AGMEMOD are high, as time series for the parameter estimations are required to cover not only the supply side of agriculture but also different types of usages as well as processing. Each country model is based on a database of annual time series, covering, when possible, a period from 1973 to the latest available year. AGMEMOD's database includes balance sheets for all primary agricultural commodities and most food processing commodities, generally including prices, production, imports and exports, opening and ending stocks as well as food, feed and other consumption. Country experts collect and validate data from various sources, e.g. national statistics, Eurostat for European Countries and FAO.

The represented agricultural sectors differ across countries depending on their importance in the respective country. For each commodity in each country agricultural production as well as supply, demand, trade, stocks and domestic prices are determined in equations with econometrically estimated or calibrated parameters. One element of the supply and demand balance for each commodity is used as a closure variable to make the balance consistent. The functional forms of the estimated equations differ between countries and commodities. In this way the equations can be adjusted to differences in agricultural systems, policy instruments or data availability. These country models are then integrated into a general model, capturing all represented models as well as the rest of the world. This approach captures the heterogeneity of agricultural systems in the various countries, while simultaneously maintaining analytical consistency across the estimated country models. Projections are possible on a yearly basis up to 2030 . These projections are mainly driven by world market prices for represented products, agricultural policies and macroeconomic variables such as GDP and population. Through changes in these drivers - especially the policies - their impact on agricultural markets can be analyzed. 
AGMEMOD provides output on annual bases and for each represented country. The main outputs are prices in $€$ or national currencies as well as production, demand, and net trade volumes in metric tons. AGMEMOD's sectoral representation is presented in Appendix 1, Table A1.1. For this assignment, sectoral details are aggregated to report on the following crops: wheat, barley sugar beets and tomatoes. For livestock sectors, the report will show outcomes for beef, pig meat, sheep meat, poultry meat, butter, skimmed milk powder and cheese.

\section{Complementary pre-modelling research}

In order to pursue the scenario analyses at sector level with the AGMEMOD tool, three issues raised in the scenarios require complementary research before a thorough quantitative assessment can be made, due to model limitations. These issues are: the representation of the horticultural sector, the simulation of bilateral trade flows between UK, other EU member states and non-EU third countries, and the estimation of restrictions on the use of hired (migrant) labour. More specifically:

- As regards horticulture AGMEMOD has only a limited representation of this sector (e.g. tomatoes are in, but further vegetable product detail is missing). Moreover, as the sector has not had much attention in most recent EU-wide market outlook analyses, the model's database needs some updating, next to additional econometric estimation of supply/demand relations of horticultural products. For this study it is proposed to do a complementary analysis, using the dataset of the model but also expert information, to estimate product price and (labour) cost impact of the different scenarios. This information will then be used to assess the likely impacts on domestic (UK, Netherlands and EU26) supply, demand and trade. Given available data, product detail of our analyses will distinguish between the categories vegetables, fruits and ornamentals. Wageningen Economic Research and the client will discuss options if the client would like to have further product detail.

- The impact of UK trade agreements with third countries needs a complementary analysis of current bilateral trade data and will use expert information to estimate the relevant (tariff rate) quota levels for different products as well as their expected filling rates. Information on this will be preferably based on estimates used by the EU Commission (see EU Aglink database). Next to expert information, applied economic reasoning on efficient UK procurement will be used. The results of this analysis will be used in the modelling exercise.

- The AGMEMOD model is a net trade model that does not include bilateral trade flows between UK, other EU member states and non-EU third countries. For this project the Dutch net trade will be disaggregated into Dutch exports to the UK, Dutch exports to the remainder of the EU (other EU member states) and Dutch exports to third countries (outside the EU). For these categories associated behavioral equations will be estimated. The methodology that will be followed for this has been discussed with modelling experts during the recent World Outlook conference (Dublin, 8-9 June). Due to this disaggregation some adjustments to the model structure have to be made also. In addition also for key products the net trade equations of the UK will be decomposed into imports from EU member states and a remainder category

The analyses proposed above will involve a number of assumptions and choices that will be discussed with the client. After mutually agreement on these assumptions, the results will be used in the modelling analyses, allowing the main impacts to be included in the quantitative assessment (which also helps to keep consistency in the analysis). 
Table A1.1 Sectoral representation in AGMEMOD

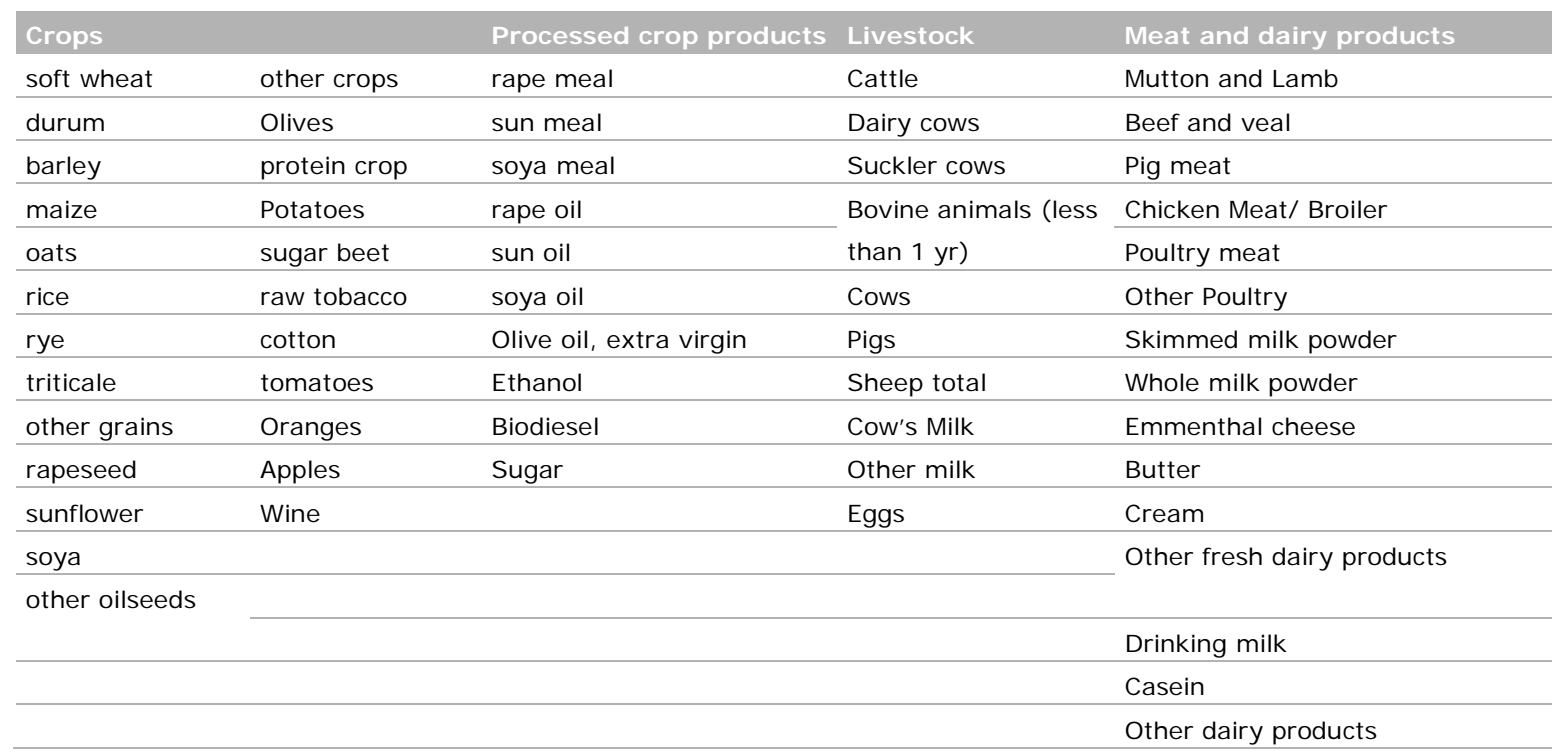




\section{Appendix 2 Interviews with the industry highlighting non-tariff issues in trade}

Interviews were held with representatives of the fresh fruit, dairy and propagation sector to discuss the market position of the sector's products exported to the UK, as well as their expectations with regard to effects of Brexit on the business of their sector. A short summary of the interviews is presented below. In addition, bilateral trade figures of the commodities under consideration in these interviews are presented in Appendix 3 below.

Fresh vegetables (tomatoes) ${ }^{14}$

Main customers in the UK are the large super market chains who use purchasing organisations. Next to Germany, the UK is the largest export market for Dutch fresh fruits and vegetables. Spain is the main competitor in Europe, also at the UK market, with the remark that due to seasonal production cycles Spain's vegetable supply is much less during the period July-October. Exports to the UK market are peaking during the summer period: for instance two-third of UK imports of tomatoes are from the Netherlands. About 15\% of Dutch tomato production areas are depending on sales in the UK. Next, the Netherlands re-exports much fruits and vegetables imported for other EU and/or third countries.

Much concern is about how the UK will design its trade standards with regard to food safety, quality and phytosanitary requirements after Brexit. In future, export inspections will be required but the UK may also decide to conduct import inspections at its border. That will bring about substantial trade costs, in terms of extra labour and administrative costs, next to additional (waiting) time at the border (reducing the quality of fresh perishable products). The sector would like to see early agreements with the UK on testing and controlling of fruit and vegetables. A pro-active attitude should lead to link digital systems to manage international trade related documents and safe time and costs.

Dairy (cheese) ${ }^{15}$

UK customers of Dutch cheese traders are mainly the retail sector, working through purchasing organisations (like with vegetables). Dutch cheese exported is (semi) hard cheese, different from soft cheeses or cheddar types of cheeses, exported by most other countries. The Dutch product is known as a quality product.

About $2 \%$ of Dutch production and $4 \%$ of total exports of cheese finds its way to the UK. Next, exports from the Netherlands also consists of re-export or transit of imported cheese from other countries. Demand for cheese in the UK is constant and the Dutch industry is not expecting much to change, also because the UK is not self-sufficient in cheese.

Trade with the UK after Brexit will imply additional costs as trade deals have to include documents that will show compliance with quality and food safety requirements. For ingredients imported from other countries and included in the export product, veterinary requirements need to be checked and complied with. At this stage, no one knows what future procedures and/or requirements will be and this creates a lot of uncertainty. In case the shipment is disapproved, trade costs may be huge, especially when no alternative market is being found.

Trade impacts of Brexit may spread from affecting internal EU trade to the international market. For instance, interviewees wonder how trade relations of the UK with New Zealand (old historical ties) may evolve.

\footnotetext{
${ }^{14}$ Mrs. Inge Ribbens, policy officer International Affairs, GroentenFruitHuis

${ }^{15}$ Mrs. Tjitske Bolt, International Dairy Affairs, NZO; Karen Spruijt, policy officer Veterinary issue at Zuivel.nI.
} 
Propagation material (bulbs and live plants) ${ }^{16}$

The bulb sector has a rather unique, strong position in the UK, selling to consumers via retailers or online, and to growers. The live plant sector is trading with municipalities, garden centres and so on. Although quality is a major competitive attribute, sales are price-sensitive. The depreciation of the British Pound (since J une 2016) caused Dutch bulb suppliers to decrease their price (retail is in charge!) and more competition for the live plants exporters.

With regard to future expectations of impacts of Brexit, the UK being a third country, much about possible trade barriers that can occur is uncertain, and hence, projecting trade impacts is hypothetical. Third countries are normally (based on the sector's experiences) stricter in applying phytosanitary measures (sometimes just because of protectionist sentiments). The UK has already announced to implement risk-based inspections, which means more inspections should be expected, rules on tolerance (minimum residues etc) will be more stringently applied and the UK may likely sharpen its testing methods. For live plants this change may result in less exports, as risks on diseases are relatively high and the sentiment of protecting own local production may be strong, whereas in this context bulb exports may benefit from the rather unique position that the UK does not produce these produce itself. Cost estimates are subject to several assumptions and hence speculatively, but remain most likely limited to 5-6fte extra for the whole sector (one fte may cost 100kE). The sector is expected to have to bear these costs. What will probably have much more impacts than these additional costs related to administrative personnel, is the costs of rejected trade: tougher inspections will increase risks of trade not meeting the requirements. A condemned cargo that has to be taken back may mean a loss of millions of euros for the exporter/grower involved.

\footnotetext{
${ }^{16}$ Interviewee: Henk Westerhof, chairman of Anthos (the Royal Trade Association for Nursery Stock and Flower Bulbs)
} 


\section{Appendix 3 Dutch trade data for selected sector (related to Appendix 2)}

Tomatoes

Table A3.1 Dutch exports to and imports from the UK of tomatoes (fresh or chilled), ${ }^{1} 2016$

\begin{tabular}{|c|c|c|c|c|c|c|c|}
\hline & \multicolumn{4}{|l|}{$€ \mathrm{~m}$} & \multicolumn{3}{|c|}{ As $\%$ total } \\
\hline & UK & $\begin{array}{l}\text { Rest of } \\
\text { the EU }\end{array}$ & Extra-EU & Total & UK & $\begin{array}{l}\text { Rest of } \\
\text { the EU }\end{array}$ & Extra-EU \\
\hline Export from the Netherlands to & 213 & 1128 & 104 & 1445 & 15 & 78 & 7 \\
\hline Imports to the Netherlands from & 1.2 & 165 & 35 & 201 & 1 & 82 & 17 \\
\hline
\end{tabular}

1) Code 0702.

Source: EUROSTAT COMEXT; adaptation Wageningen Economic Research.

Table A3.2 UK exports to and imports from the Netherlands of tomatoes (fresh or chilled), 2016

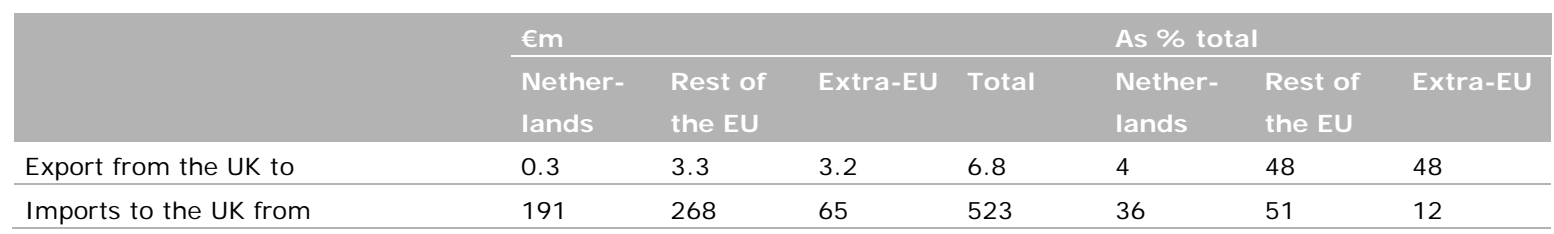

Source: EUROSTAT COMEXT; adaptation Wageningen Economic Research.

Poultry meat

Table A3.3 Dutch exports to and imports from the UK of poultry meat, ${ }^{1} 2016$

\begin{tabular}{|c|c|c|c|c|c|c|c|}
\hline & \multicolumn{4}{|l|}{$€ \mathrm{~m}$} & \multicolumn{3}{|c|}{ As $\%$ total } \\
\hline & UK & $\begin{array}{l}\text { Rest of } \\
\text { the EU }\end{array}$ & Extra-EU & Total & UK & $\begin{array}{l}\text { Rest of } \\
\text { the EU }\end{array}$ & Extra-EU \\
\hline Imports to the Netherlands from & 32 & 430 & 133 & 595 & 5 & 72 & 22 \\
\hline
\end{tabular}

1) Code 0207 - Meat and edible offal of fowls of the species gallus domesticus, ducks, geese, turkeys and guinea fowls, fresh, chilled or frozen. Source: EUROSTAT COMEXT; adaptation Wageningen Economic Research.

Table A3.4 UK exports to and imports from the Netherlands of poultry meat, 2016

\begin{tabular}{|c|c|c|c|c|c|c|c|}
\hline & \multicolumn{4}{|l|}{$€ m$} & \multicolumn{3}{|c|}{ As $\%$ total } \\
\hline & $\begin{array}{l}\text { Nether- } \\
\text { lands }\end{array}$ & $\begin{array}{l}\text { Rest of } \\
\text { the EU }\end{array}$ & Extra-EU & Total & $\begin{array}{l}\text { Nether- } \\
\text { lands }\end{array}$ & $\begin{array}{l}\text { Rest of } \\
\text { the EU }\end{array}$ & Extra-EU \\
\hline Imports to the UK from & 531 & 677 & 40 & 1249 & 43 & 54 & 3 \\
\hline
\end{tabular}

Source: EUROSTAT COMEXT; adaptation Wageningen Economic Research. 


\section{Cheese}

Table A3.5 Dutch exports to and imports from the UK of cheese ${ }^{1)}, 2016$

\begin{tabular}{|c|c|c|c|c|c|c|c|}
\hline & \multicolumn{4}{|l|}{$€ m$} & \multicolumn{3}{|c|}{ As \% total } \\
\hline & UK & $\begin{array}{l}\text { Rest of } \\
\text { the EU }\end{array}$ & Extra-EU & Total & UK & $\begin{array}{l}\text { Rest of } \\
\text { the EU }\end{array}$ & Extra-EU \\
\hline Imports to the Netherlands from & 52 & 812 & 35 & 899 & 6 & 90 & 4 \\
\hline
\end{tabular}

1) Code 0406 - Cheese and curd.

Source: EUROSTAT COMEXT; adaptation Wageningen Economic Research.

Table A3.6 UK exports to and imports from the Netherlands of cheese, 2016

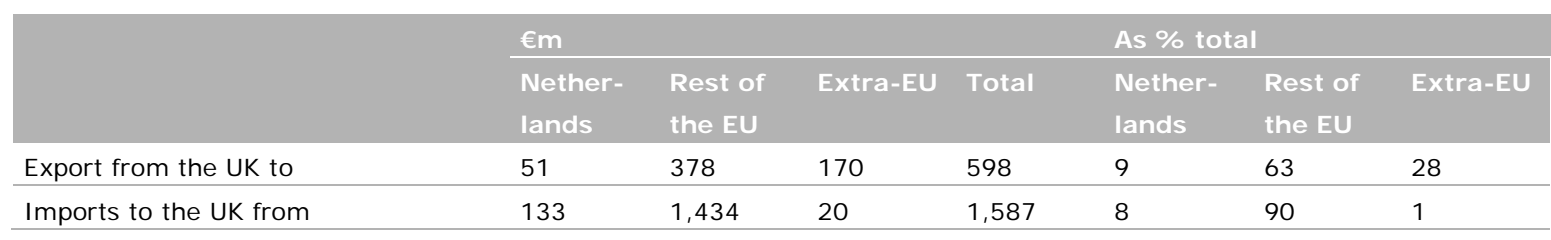

Source: EUROSTAT COMEXT; adaptation Wageningen Economic Research.

Propagation material

Table A3.7 Dutch exports to and imports from the UK of propagation material, ${ }^{1} 2016$

\begin{tabular}{|c|c|c|c|c|c|c|c|}
\hline & \multicolumn{4}{|l|}{$€ m$} & \multicolumn{3}{|c|}{ As $\%$ total } \\
\hline & UK & $\begin{array}{l}\text { Rest of } \\
\text { the EU }\end{array}$ & Extra-EU & Total & UK & $\begin{array}{l}\text { Rest of } \\
\text { the EU }\end{array}$ & Extra-EU \\
\hline \multicolumn{8}{|c|}{ Export from the Netherlands to } \\
\hline Bulbs & 64 & 389 & 503 & 955 & 7 & 41 & 53 \\
\hline Live plants & 281 & 1,847 & 408 & 2,536 & 11 & 73 & 16 \\
\hline \multicolumn{8}{|c|}{ Imports to the Netherlands from } \\
\hline Bulbs & 0.3 & 3.7 & 57 & 61 & 1 & 6 & 93 \\
\hline Live plants & 3.8 & 235 & 174 & 413 & 1 & 57 & 42 \\
\hline Total & 4.1 & 239 & 231 & 474 & 1 & 50 & 49 \\
\hline
\end{tabular}

1) Only codes 0601 - Bulbs, tubers, tuberous roots, corms, crowns and rhizomes, dormant, in growth or in flower, chicory plants and roots (excl. bulbs, tubers and tuberous roots used for human consumption and chicory roots of the variety cichorium intybus sati; and 0602 - Live plants incl. their roots, cuttings and slips; mushroom spawn (excl. bulbs, tubers, tuberous roots, corms, crowns and rhizomes, and chicory plants and roots); 2) Total refers to the sum of 0601 and 0602.

Source: EUROSTAT COMEXT; adaptation Wageningen Economic Research.

Table A3.8 UK exports to and imports from the Netherlands of propagation material, 2016

\begin{tabular}{|c|c|c|c|c|c|c|c|}
\hline & \multicolumn{4}{|l|}{$€ m$} & \multicolumn{3}{|c|}{ As $\%$ total } \\
\hline & $\begin{array}{l}\text { Nether- } \\
\text { lands }\end{array}$ & $\begin{array}{l}\text { Rest of } \\
\text { the EU }\end{array}$ & Extra-EU & Total & $\begin{array}{l}\text { Nether- } \\
\text { lands }\end{array}$ & $\begin{array}{l}\text { Rest of } \\
\text { the EU }\end{array}$ & Extra-EU \\
\hline Bulbs & 1.7 & 2.1 & 1.9 & 5.7 & 29 & 37 & 34 \\
\hline Live plants & 1.9 & 20 & 4.2 & 27 & 7 & 77 & 16 \\
\hline \multicolumn{8}{|c|}{ Imports to the UK from } \\
\hline Bulbs & 70 & 10 & 0.2 & 80 & 87 & 12 & 0 \\
\hline Live plants & 217 & 88 & 8.1 & 314 & 69 & 28 & 3 \\
\hline Total & 288 & 98 & 8.3 & 394 & 73 & 25 & 2 \\
\hline
\end{tabular}

Source: EUROSTAT COMEXT; adaptation Wageningen Economic Research. 


\section{Appendix 4 Trade elasticities explained}

In order to better understand the outcomes of our simulations, further insight into the price response of exports to the UK as these are included in the AGMEMOD model is welcome. As has been briefly indicated in the main text, Dutch exports $\left(\mathrm{X}_{\mathrm{NL}}\right)$ are differentiated with respect to three export destinations, namely the UK, the rest of the EU27 and the rest of the world (ROW). For this a set of export share equations has been empirically estimated, using trade data for the period 2000-2016. The export share $s_{i}$ has been estimated as a function of domestic price, the UK price and the EU-prices (approximated by the key-price as it is in the model). Algebraically, the export share equation for the UK can be written as follows (the goods subscript has been suppressed for convenience sake)

$$
s_{U K}=s_{U K}\left(p_{U K}, p_{E U}, p_{R o W}\right)
$$

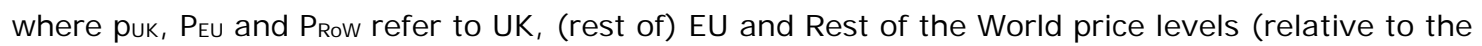
Dutch price), while the equation for the total Dutch exports is specified to a function of domestic, EU and world market prices, or

$$
x_{N L}=x_{N L}\left(p_{N L}, p_{E U}, p_{R o W}\right)
$$

with $\mathrm{p}_{\mathrm{NL}}$ referring to the real Dutch price (deflated by a cost index). The exports of Netherlands to the UK, $\mathrm{XNL}_{\mathrm{NL}} \mathrm{UK}$ can then be written as

$$
x_{N L-U K}=s_{U K}(.) \cdot x_{N L}(.)=x_{N L-U K}\left(p_{N L}, p_{U K}, p_{E U}, p_{R o W}\right)
$$

Note that the exports are denoted in volume (physical product) rather than value. So, suk is equal to $\mathrm{XNL}_{\mathrm{UK}} / \mathrm{XNL}_{\mathrm{N}}$. The export elasticity indicates by what percent the (volume of) exports changes as a response to a change in the export price. When doing some algebra it turns out that the export elasticity of Dutch exports to the UK, with respect to the price Dutch exporters get when exporting to the UK, puk, is equal to the share equation elasticity with respect to the UK price, or

$$
\frac{\partial x_{N L-U K}}{\partial p_{u k}} \frac{p_{U K}}{x_{N L-U K}}=\varepsilon_{N L-U K, p u k}=\frac{\partial s_{U K}}{\partial p_{U K}} \cdot x_{N L-U K} \cdot \frac{p_{U K}}{x_{N L-U K}}=\frac{\partial s_{U K}}{\partial p_{U K}} \frac{1}{s_{U K}} \cdot \frac{p_{U K}}{x_{N L-U K}}=\varepsilon_{s_{U K-P u k}}
$$

The partial derivatives in the above equation coincide with estimated parameter values. When choosing a point for evaluation (e.g. a recent year such as 2016), the export elasticities can be calculated (directly from the share equations). These export elasticities provide a measure for assessing how trade flows (Dutch exports) will be reallocated when relative prices change to specific export destinations. Table A4.1 provides the Dutch export price elasticities with respect to the UK. 
Table A4.1 Dutch export price elasticities ${ }^{17}$ in its trade with the UK

\begin{tabular}{|c|c|c|c|}
\hline \multirow[t]{2}{*}{ Product } & \multicolumn{3}{|c|}{ Own-price elasticity of Dutch exports to region i with respect to the price of region $\mathrm{i}$} \\
\hline & UK & EU-26 & Row \\
\hline beef & 0.80 & 0.15 & 0.84 \\
\hline poultry & 0.32 & 0.67 & 0.23 \\
\hline cheese & 0.80 & 0.07 & 0.26 \\
\hline
\end{tabular}

Source: own calculations based on the export-share equations (first order effects). ${ }^{18}$

As the first column of Table A4.1 shows the export share (and thus also the export volume elasticities as was shown in the elasticity derivation above) are inelastic (less than 1 ). As an example, as the price Dutch exporters receive when exporting to the UK increases by $10 \%$, the exports to the UK will increase by 8 percent, or less than proportionally. When the price Dutch exporters receive declines (e.g. due to a 5 percent trade facilitation cost wedge), the export volume to the UK will decline by $4 \%$ $(-5 \times 0.80=-4)$. This inelastic own-price response also holds for the own export price elasticities for the other destinations: the rest of the EU (EU-26) and rest of the world (RoW).

To what extent does Table A4.1 help to understand the changes in Dutch exports to the UK after a Brexit as indicate by our model simulations? It should be noted that the elasticities provided in Table A4.1 provide partial responses, namely how the Dutch exports to the UK change if the UK price changes, and is conditional to the fact that everything else will not change and stay the same as it is. In reality, Brexit will not only lead to a change in the UK price Dutch exporters receive, but at the same time also lead to adjustments in other prices. To feed the intuition: a Brexit can lead to a decline in the export price Dutch exporters receive because of the trade facilitation cost wedge (e.g. which under an FTA scenario can potentially lead to a $5 \%$ price reduction). But at the same time the price in the rest of the EU is likely to decline a bit too, because if all countries face more difficulties to export to the UK, this will lead to additional supply on the EU market, and hence a downward pressure on all EU market prices. As a consequence, producers start to respond by reducing production. But this latter effect reduces the initial relative price change due to the change in the UK price. Some insight into the complexities one has to face in disentangling all the effects can be derived when using the (implicit) export share equation (see also above)

$$
x_{N L-U K}=x_{N L-U K}\left(p_{N L}, p_{U K}, p_{E U}, p_{R o W}\right)
$$

and totally differentiate this with respect to the UK price (while making use of the share-equation linkage found above). Doing this the change in Dutch exports to the UK ( $d x_{N L-U K}$ ) relates to a UK price (duk) according to

$$
d x_{N L-U K}=\frac{\partial s_{U K}}{\partial p_{N L}} \cdot \frac{\partial p_{N L}}{\partial p_{U K}} d p_{U K}+\frac{\partial s_{U K}}{\partial p_{U K}} d p_{U K}+\frac{\partial s_{U K}}{\partial p_{E U}} \cdot \frac{\partial p_{E U}}{\partial p_{U K}} d p_{U K}+\frac{\partial s_{U K}}{\partial p_{R o W}} \cdot \frac{\partial p_{R o W}}{\partial p_{U K}} d p_{U K}
$$

which includes price interaction effects of different destinations (including the Dutch home market) with respect to the UK price (e.g. $\left(\partial p_{-} N L\right) /\left(\partial p_{-} U K\right),\left(\partial p_{-} E U\right) /\left(\partial p_{-} U K\right)$, and $\left.\left(\partial p_{-} R o W\right) /\left(\partial p_{-} U K\right)\right)$. In a model simulation all these interaction effects are directly accounted for, because they are part of the new equilibrium established by the model. Note that the EU-UK price interaction effect $\left(\left(\partial p_{-} E U\right) /\left(\partial p_{-} U K\right)\right)$ will not only depend on what happens with respect to the Netherlands and the UK, but also will be influenced by the effects a Brexit imposes on the trade relationship and reallocation of trade flows with all other EU Member States. If, for example, in the case of pork a number of Member

\footnotetext{
${ }^{17}$ The elasticities refer to relative (or real) price changes. They are obtained using econometric estimation, usually over the period 2000-2017. In some cases additional constraints had to be imposed to come to reliable estimates. The statistical diagnostics on parameter significance ( $t$-values), goodness of fit (R-square) and predictive power (Root means square error) indicated that there is uncertainty associated with the found parameters and the derived elasticities. This should be accounted for when interpreting the results.

${ }^{18}$ In the model also cross-price elasticities are included, which can create additional (second order) indirect effects. Note that as $x_{N L}$ is a function of $p_{E U}$ and prow aside of a direct effect, a change in these prices will also affect total Dutch exports $\mathrm{X}_{\mathrm{NL}}$. These latter impacts are in general very small and therefore here ignored in the calculation as being second order effects.
} 
States succeed in reallocating their exports to the Rest of the World, this will release the pressure on the EU market and by that reduces the EU price decline induced by the change of the UK price. But if other Member States start to export more to the Rest of the World, this could create opportunities for the Netherlands to keep exporting to the UK and to the Rest of the EU, for example because it is competitive in these markets, relative to other Member States. Note again that in a Brexit simulation with AGMEMOD all these impacts, also those involving the responses of all other EU member states, occur simultaneously and are resolved for in a new market equilibrium (and associated reallocated trade flows).

The complexity of interaction effects and the fact that in other studies no information is provided about the elasticity responses they have included in their used modelling tools, makes it difficult to compare the differences between our study and other studies in this respect. However, the underlying elasticity information will be reflected in the final outcomes, even though impacts will not be traceable to specific parameters or elasticities. Comparing our results to Davis et al. (2017, see especially their appendix) shows that in their study the substitution between EU products and those from third (nonEU) countries is high. This implies that according to their results, a Brexit will lead to much bigger shifts in trade flows, with the UK replacing imports from the EU by imports from the world market. According to our results this substitution is there, but at a much more limited scale and also depending on the scenario that is analysed. One way to explain this difference could be that in our estimates (which are based on econometric estimation using historical data) the response to relative price changes is more limited, because aside from profitability there are also other factors that matter, such as product differentiation, ${ }^{19}$ institutional factors (e.g. having a well-developed delivery structure) and trust (e.g. sourcing reliability, on-time delivery, high product-quality) play a role in the 'channelling' of bilateral trade flows. As such the price-aspect is only one part of a larger story.

\footnotetext{
19 In the model the assumption is made that goods are homogeneous and that, say pork meat from the Netherlands, can be replaced by similar pork meat from, for example, the US. However, in reality products differ in variety (heterogeneity) and what in the model is aggregated into 'pork meat' can refer to different meat components of the pig (e.g. loin, belly, ham, blade). If for example, by exporting ham, Dutch exports service a specific niche market in the UK, this is likely to turn out in model estimation as resulting in a relative low price response of Dutch exports to a change in the UK price, which then in this way accounts for the specific quality of the Dutch product in relation to a specific pig meat (part) demand in the UK.
} 
Wageningen Economic Research P.O. Box 29703

2502 LS The Hague

The Netherlands

T +31 (0)70 3358330

E communications.ssg@wur.nl

www.wur.eu/economic-research

Wageningen Economic Research REPORT

2018-026
The mission of Wageningen University and Research is "To explore the potential of nature to improve the quality of life". Under the banner Wageningen University \& Research, Wageningen University and the specialised research institutes of the Wageningen Research Foundation have joined forces in contributing to finding solutions to important questions in the domain of healthy food and living environment. With its roughly 30 branches, 5,000 employees and 10,000 students, Wageningen University \& Research is one of the leading organisations in its domain. The unique Wageningen approach lies in its integrated approach to issues and the collaboration between different disciplines. 



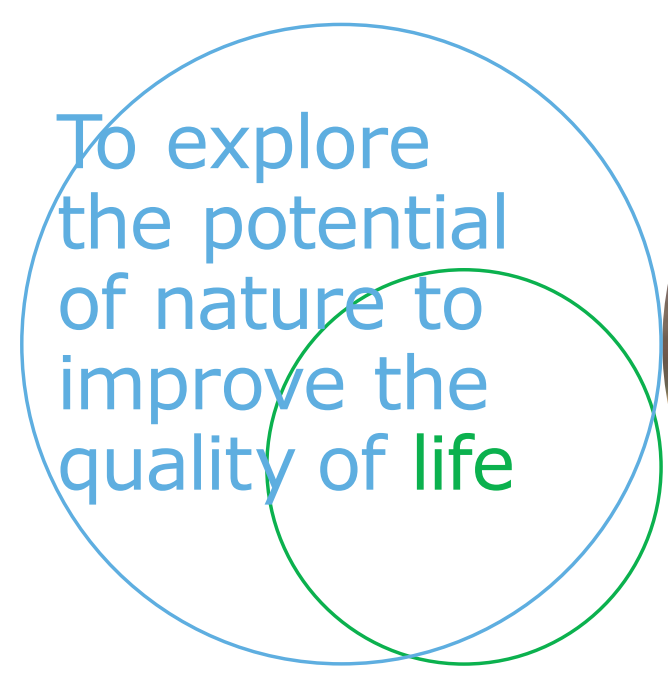

Wageningen Economic Research P.O. Box 29703

2502 LS Den Haag

The Netherlands

E communications.ssg@wur.nl

www.wur.eu/economic-research

Report 2018-026

ISBN 978-94-6343-261-0

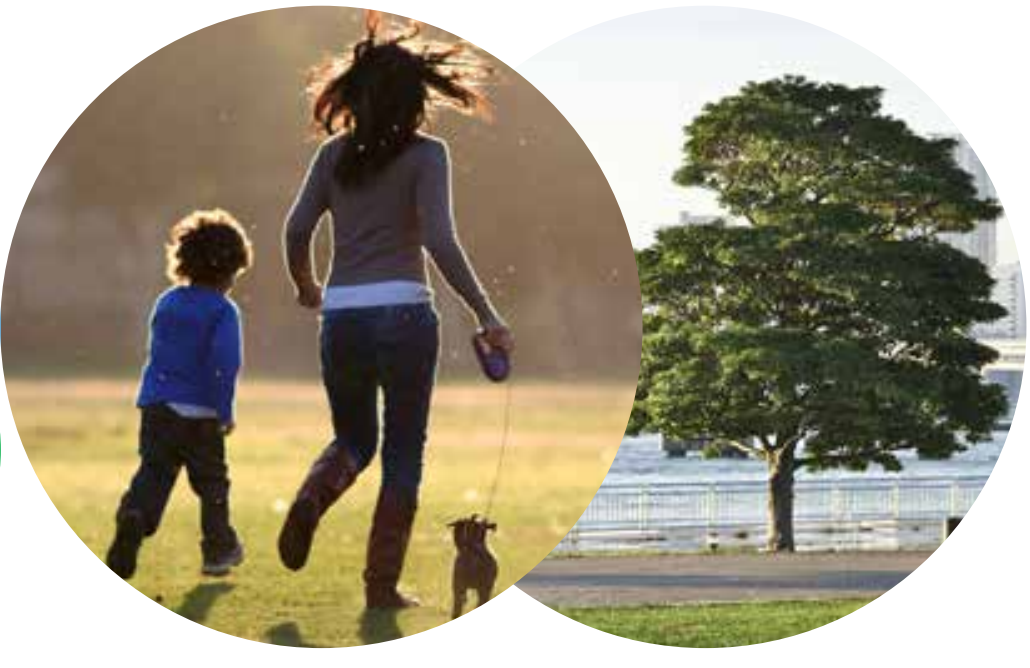

The mission of Wageningen University and Research is "To explore the potential of nature to improve the quality of life". Under the banner Wageningen University \& Research, Wageningen University and the specialised research institutes of the Wageningen Research Foundation have joined forces in contributing to finding solutions to important questions in the domain of healthy food and living environment. With its roughly 30 branches, 5,000 employees and 10,000 students, Wageningen University \& Research is one of the leading organisations in its domain. The unique Wageningen approach lies in its integrated approach to issues and the collaboration between different disciplines. 